\title{
Hybrid Renewable Energy Supply for Rural Healthcare Facilities: An Approach to Quality Healthcare Delivery
}

\author{
Lanre Olatomiwa $^{1,2}$ *, Richard Blanchard ${ }^{1}$ Saad Mekhilef ${ }^{3}$, Daniel Akinyele ${ }^{4}$
}

\author{
${ }^{1}$ Centre for Renewable Energy Systems Technology, Loughborough University, LE11 3TU, UK \\ ${ }^{2}$ Department of Electrical \& Electronic Engineering, Federal University of Technology, PMB 65, Minna. Nigeria \\ ${ }^{3}$ Power Electronics and Renewable Energy Research Laboratory (PEARL), Department of Electrical Engineering, \\ University of Malaya, 50603 Kuala Lumpur, Malaysia \\ ${ }^{4}$ Department of Electrical and Computer Engineering, Elizade University, PMB 002, Ilara-Mokin, Nigeria
}

\begin{abstract}
The lack of modern electricity supply has been a major impediment to proper functioning of the healthcare centers in the rural areas, contributing to high maternal and child mortality rates in a country. Therefore, this study focuses on how to address the identified problem so that the healthcare centers or clinics in the remote areas can provide timely delivery of medical services for the concerned people. This paper, then, presents the analysis of stand-alone hybrid renewable energy systems for basic healthcare services in the rural areas, where there is no grid energy supply or the supply from the existing grid is erratic and unreliable. One major factor that informs the selection of the hybrid energy system in this study is that it promises high reliability compared to a single energy system. The research presents a statistical analysis of the potential of wind and solar energies for a selected rural locations in Nigeria based on the available long-term hourly and daily meteorological data. It employs an optimal technical and economic design and sizing of hybrid electrical power systems' components such as the wind, PV, battery and inverter systems, using the hybrid optimisation software (HOMER). Results show that Sokoto and Jos sites exist in the high wind potential regions, while the remaining sites are only suitable for small wind applications. Values obtained for global radiation show that all the sites enjoy considerable solar energy potential suitable for varying degree of solar energy applications. PV/wind/diesel/battery hybrid system configuration is considered optimum for rural health center at Iseyin, Sokoto, Maiduguri, Jos and Enugu, while hybrid systems involving PV/diesel/battery is considered ideal for Port-Harcourt, due to the quality of renewable energy potential. Hence, it was concluded that, the abundance of wind and solar resources in the country create an ideal environment for inclusion of renewable energy systems in the design and implementation of standalone power supply systems to improve rural healthcare delivery.
\end{abstract}

Keywords: electricity demand, energy supply, healthcare services, renewable energy, reliable supply

* Corresponding Author address

Email:olatomiwa.l@futminna.edu.ng

\section{INTRODUCTION}

Reliable electricity access is a pre-requisite for improving the social and economic lives of the people in rural areas. It enhances healthcare delivery, education as well as other developmental growth within the local communities. At present, $17 \%$ of world population have no access to electricity, $85 \%$ of which lives in rural areas of Sub-Saharan Africa (SSA), South Asia and other developing countries, with SSA having the largest share of the electricity deficit rate [1].

The majority of these people have limited prospects of gaining access to electricity in the near future. The implication of this can be translated as close to 1 billion people around the world are being served with 
healthcare facilities with no electricity access [2]. This deficiency implies that medical equipment such as ultra sound, autoclave, centrifuge and medical x-ray cannot be used in such places as presented in Figure 1. Surgery services sometimes delivered by depending on the ambient light from windows or kerosene lamps at nights. Reports indicated that, quite a number of women die on a daily basis during pregnancy and childbirth in rural places due to poor medical care. By providing at least a minimum lighting and electric power supply to minor surgical equipment could reduce the high maternal mortality rate by $70 \%$ [2].

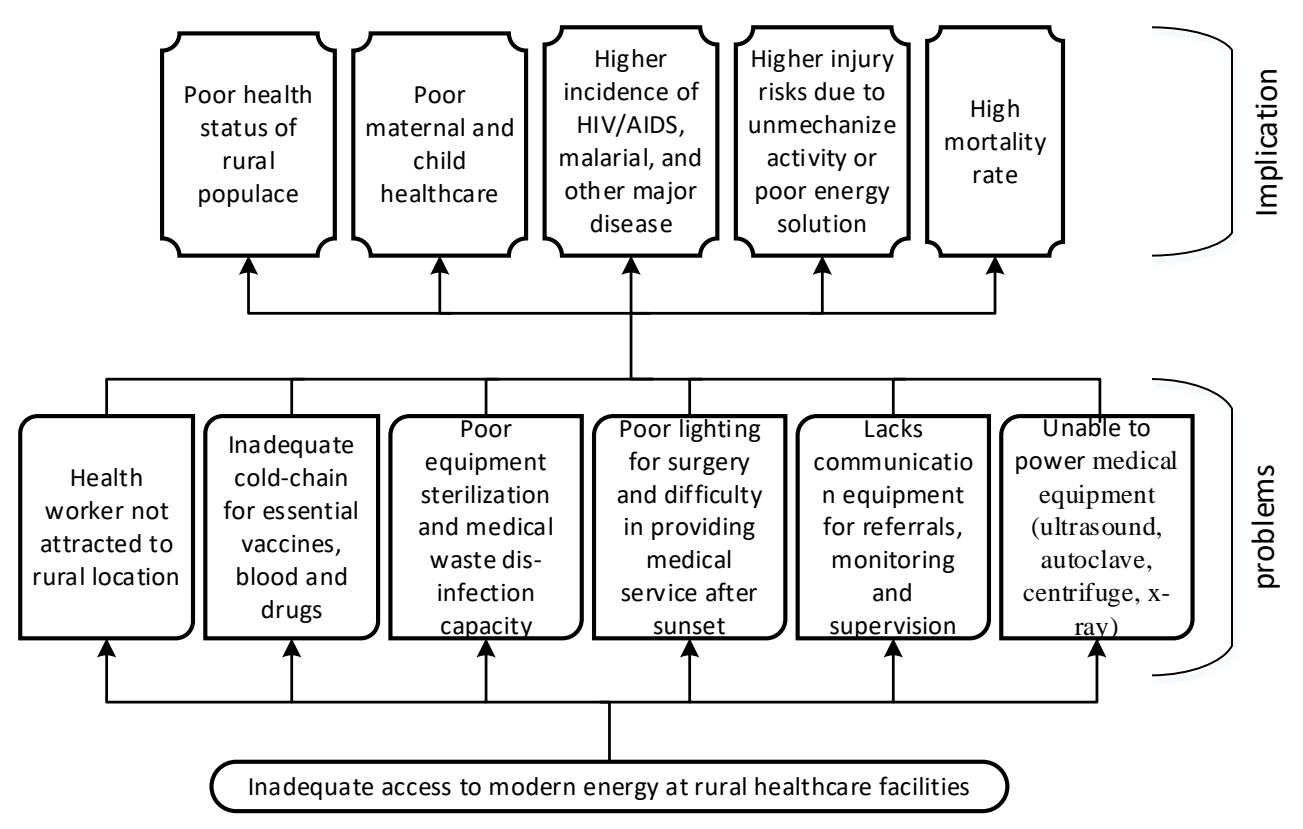

Figure1: Impact of energy access on rural healthcare services

Diesel generators have traditionally been used to power most off-grid clinics and hospitals for supplementing the unreliable grid supply for grid-connected facilities, but this is associated with attendant costs of diesel fuel and unreliable delivery as well as high $\mathrm{CO}_{2}, \mathrm{CO}$ and particulate emissions contributing to air pollution and climate change.

The rural health sector in developing nations are challenged with several problems, which have hindered effective delivery of healthcare services to the people living in the rural communities. For instance, unreliable power supply can render cold-chain activities inoperable; furthermore, the lack of illumination (light) at the clinics at nights usually keeps patients arriving late in the night for medical attention to wait until the following morning before medical attention can be rendered to them. This has led to many problems including obstetric complications, which is one of the root causes of high maternal mortality rate in sub-Saharan Africa region [3]. A lack of antenatal care, absence of skilled birth attendants and limited availability of emergency obstetrics procedures due to lack of electricity are reasons for this situation. Therefore, electricity should be a priority for effective public healthcare delivery.

In rural areas with no access to electricity from the grid, renewable energy technology could be a viable option.These alternative technologies for producing electricity have received greater attention in recent years, due to their cost effectiveness in operation, environmental friendliness as well as sustainability [4-12]. In the case of rural health facilities, a solar/wind/diesel generator hybrid system can be deployed to cater for the need of un-electrified rural health centers. It will provide means to power critical lighting, mobile communication 
devices and certain medical equipment for delivering timely and critical medical care for the rural dwellers. Hence, the role of energy supply in healthcare services delivery in the rural areas where there is no grid extension or reliable power supply cannot be over emphasized.

Renewable energy sources have proven their ability to contribute substantially to global climate protection efforts by reducing the greenhouse gas emission while meeting rapid energy growth demand [13-19]. However, in technical terms, a system that wholly depends on single-source renewable energy alone is not necessarily considered reliable, especially for isolated loads in remote areas [4]. This is because electricity supply through a renewable energy source that has a variable or intermittent characteristic, may not guarantee energy production be available at all times. This is why a hybrid power system that combines more than one source, e.g. conventional and renewable energy systems or two/more renewable energies, are proposed. A properly selected renewable power system is expected to considerably reduce the need for fossil fuel system use by ensuring a relatively higher renewable energy penetration. Such a system is also expected to achieve a reliable power supply, as theconventional power sources will assist the renewable sources during varying environmental conditions, by balancing the electrical power. Therefore, a hybrid system consisting of solar PV, wind, battery and diesel generator systems can be considered a better option for isolated loads. Such an option, where the wind and solar PV systems are used as main sources of energy, while the diesel generator serves as a backup source, and battery bank as a storage system is expected to; (i) satisfy the energy demands,(ii) minimize the costs, (iii) maximize the utilization of renewable sources, (iv) optimize the operation of battery bank, (v) ensure efficient operation of the diesel generator, and (vi) reduce environment pollution emissions.

Several research studies on off-grid energy systems analysis exist in the literature for both singlesource and hybrid configurations. This paper provides a brief survey on them. The techno-economic design of hybrid systems has been discussed [5]. The techno-economic sizing of off-grid hybrid renewable energy system for rural lecetrification in Sri Lanka has been presented [20]. The design and economics analysis of an off-grid energy system has been published with a focus on the household electrification [21]. A paper has been published on techno-economic feasibility of photovoltaic, wind, diesel and hybrid electrification systems for Colombia[22]. Furthermore, the techno-economic analysis of stand-alone hybrid photovoltaic-diesel-battery systems for rural electrification in eastern part of Iran has been presented [23]. A study has been discussing which focuses on the integrated optimal design and sensitivity analysis of a standalone wind turbine system with storage for rural energy supply [24]. The techno-economic feasibility analysis of a solar-biomass off-grid system has been discussed, with focus on the electrification of remote rural areas in Pakistan using HOMER software [25]. A study has been published on the optimal design configuration using HOMER [14, 26].

In addition, a review of sustainable energy access and technologies has been discussed on healthcare facilities focusing on the global south[27]. A study has been published on off-grid systems for rural electrification in developing countries with emphasis on definitions, classifivcation and a comprehensive review [28]. A review on planning, configurations, modelling and optimization techniques has been discussed focusing on renewable energy systems for offgrid applications [29].

These existing studies provide relevant simulation, analysis and background for this current paper, especially on the technical and economic evaluation of the proposed electricity systems. The academic contributions of these studies are useful for understanding and progressing research in the area of review and the techno-economic analysis of off-grid electricity systems. However, the studies in Refs. [5, 14, 20-23, 25, 26] do not consider battery analysis, while the $\mathrm{CO}_{2}$ emissions analysis is not considered in the papers in Refs.[20, 21, 24-26]. It is of interest in this paper to cover the gaps identified in the mentioned studies by presenting a detailed simulation and analysis that includes the battery state-of-charge evalaution in the technical design, coupled with the economic and the $\mathrm{CO}_{2}$ emissions analyses. It is expected that the research results will form a useful basis for addressing the problem of a lack of energy supply for healthcare services by 
local communities and policy-makers in different Nigeria, and also for further research in the area of off-grid systems design and development.

Therefore, this research study discusses the simulation and analysis of stand-alone hybrid renewable energy systems for basic healthcare services in areas, where there is no grid energy supply or the supply from the existing grid is unreliable. It examines the energy configurations that are fueled by the available solar, wind and diesel energy resources of six different locations in Nigeria under different environmental conditions such as the solar irradiation, wind and ambient temperature. The locations used as test cases are North-east (Maiduguri), North-west (Sokoto), North-central (Jos), South-east (Enugu), South-west (Iseyin) and South-south (Port-harcourt).

The paper uses standard off-grid energy systems methodologies supported by the Hybrid Optimisation Model for Electric Renewables (HOMER) tool, International Electrotechnical Commission (IEC) standards and some relevant studies in the literature for the simulation and analysis of the proposed hybrid electricity systems for the intended healthcare centers across the country[30-36]. In addition, a real-world energy demand profile of a standard rural healthcare center in the country has been used as the basis for analysing the energy system. Such an approach provides a practical insight into understanding and ascertaining the users' energy requirements, rather than relying on assumptions. A total demand of $24 \mathrm{kWh} / \mathrm{d}$ is used in this research paper and has been estimated by considering all the different appliances in the health center and their daily hours of operation. The technical analysis involves determining the appropriate sizes of different components of the hybrid systems, their annual energy generation and the battery state-of-charge. These will be achieved by using the HOMER simulation tool to optimise the different energy models or configurations that can meet the daily energy demand of the intended healthcare centres. However, the economic analysis examines the initial capital cost, net present cost and the cost of energy, while the environmental analysis will be considered in terms of the quantity of carbon emissions that may be avoided supposing the proposed hybrid electricity systems are implemented in the specified locations. It is expected that the results of the analysis of the technical, economic and environmental aspects of the design may be useful for planning stand-alone energy generation systems for remote healthcare centres in Nigeria, and any other location around the world.

The remaining part of the paper is arranged as follows: section 2 presents the methods; section 3 is on results and discussion, while section 4 concludes the paper.

\section{MethodS}

\subsection{Renewable energy resources assessment}

Renewable energy resources can provide electricity for various uses in different off-grid rural areas around the world [37, 38]. Among the several renewable energy sources, wind and solar can be abundant and economically viable in these regions. Hence, they are commonly explored. However, a detailed study and analysis of the available long-term solar radiation and wind data of the specified location is vital for design and prediction of the energy output. Such a consideration will be helpful for determining the suitability of renewable energy resources for any specific applications.

Several investigations had been made in Nigeria on solar and wind energy assessment for power generation, but with no particular considerations for rural healthcare application. In ref. [39], solar applications and developments in Nigeria were comprehensively discussed; various irradiation levels as distributed within the six climatic region across the country were categorized into zones. Zone I comprised the 
entire states in the North-Eastern part of the country. This zone has high solar radiation incident on the horizontal surface and it has great potential for large-scale solar power, mostly in the semi-arid region. In Zone II, which is made up of the North-West and North-Central parts of the country, there is viable solar radiation, which is suitable for most solar projects. Zone III, which comprises of all locations in the southern part of the country, including the coastal region exhibits low potential of annual global solar radiation, and is only appropriate for stand-alone PV systems. Nevertheless, certain states/locations in the South-Western and SouthEastern regions are viable for decentralized energy projects. Furthermore, since there are limited meteorological sites in the country, several empirical models were developed for some locations around the country, to predict global and diffuse radiation data, needed for diverse solar applications [40-45].

Based on the existing findings, Nigeria has a low to moderate wind regime, with the wind speeds ranging from 2.12 to $4.13 \mathrm{~m} / \mathrm{s}$ in the south, excluding the coastal regions; while in the northern region, the wind speeds is considered reasonable, ranging from 4.0 to $8.60 \mathrm{~m} / \mathrm{s}$ [46, 47]. The sites considered in this study are selected from each of the six geo-political zones of the country with a site representing each of the zones. The locations are characterized by different climatic conditions and include: Iseyin (Tropical wet), Sokoto (Tropical dry), Maiduguri (Hot semi-arid), Jos (Tropical), Enugu (Humid) and Port-Harcourt (Equatorial).

In this study, various analyses have been conducted to ascertain the potential of the two proposed energy sources; wind and solar in the selected sites. The potentials of solar energy resources at the selected sites were assessment analyzed based on certain key solar resource's parameters, including monthly and annual global solar radiation (GSR). On the other hand, wind energy potentials were examined based on monthly mean daily wind speed data.

The meteorological data (wind speed and solar radiation) used in the analysis were obtained from the Nigerian Metrological Agency (NIMET), located in Oshodi, Lagos [48]. Archived daily wind speed data spanning over a period between 28 and 39 years were captured at $10 \mathrm{~m}$ height by a cup-generator anemometer at all the locations, while the daily global solar radiation on horizontal plane were measured using GunnBellani radiometer, with readings ranging between 18 and 31 years. These data were computed as average of the data for each month. The geographical information of the selected locations is presented in Table 1.

Table 1: Geographic information of the selected locations

\begin{tabular}{llllll}
\hline Location & Zone & $\begin{array}{c}\text { Latitude } \\
\left({ }^{\mathbf{}} \mathbf{N}\right)\end{array}$ & $\begin{array}{c}\text { Longitude } \\
\left({ }^{\mathbf{}} \mathbf{E}\right)\end{array}$ & $\begin{array}{l}\text { Altitude } \\
(\text { meters) }\end{array}$ & Climate type \\
\hline Iseyin & Southwest & 7.96 & 3.78 & 330 & Tropical wet \\
Sokoto & Northwest & 12.28 & 4.13 & 220 & Tropical dry \\
Maiduguri & Northeast & 11.83 & 13.15 & 353.8 & Hot semi-arid \\
Jos & North central & 9.92 & 8.9 & 1217 & Tropical \\
Enugu & Southeast & 6.45 & 7.5 & 247 & Humid \\
Port Harcourt & Southsouth & 4.78 & 7.0 & 465 & Equatorial \\
\hline
\end{tabular}

The methodology and the mathematical models for the energy systems analysis are presented in the following sub-section.

\subsection{Energy demand assessment of a rural health clinic}

The energy demand assessment is a vital step in the energy intervention planning and design process, as it provides information concerning the various types of electrical appliances, their power rating and the time of 
operation within the day. Therefore, a thorough assessment of energy demands of a healthcare facility is critical to the selection of the most suitable energy resources. For example, a health post that is the most basic health facility within the remote villages, is usually associated with medical services such as: (i) treatment of minor illnesses or injuries, (ii) child deliveries and provision of basic immunization services.

The energy need of such facilities is considered relatively low, due to limited availability of medical equipment [49]. On the other hand, a health clinic that offers a wider range of medical services than a health post, and possesses equipment that allows more medical diagnoses can be considered high in energy demands. According to United States Agency for International Development [50], healthcare facilities can generally be categorized into three.

The first category, i.e. Category I, is applicable to the rural localities and characterized with limited medical services and staff. In this category, electricity is often required for lighting during evening hour's operations and to support limited surgical procedures such as suturing, refrigeration for maintenance of coldchain vaccines and other medical supplies. Basic equipment in such a facility includes the following; a centrifuge, hematology mixer, microscope, incubator and hand-held power aspirator. The estimated load demand for this category range between $5-10 \mathrm{kWh} /$ day. The second category (Category II ), contains medical equipment that is similar to the first category, but can as well accommodate sophisticated medical diagnostic equipment with frequent usage when compared to facility in the first category. The other energy-consuming appliance that can be obtained in this category includes: refrigerators often used for food/blood bank storage, communications equipment to communicate with medical expert in referral centers. The estimated energy demand in this category is in the range of $10-25 \mathrm{kWh} /$ day. The third category, i.e. Category III usually serves as a primary referral center, because it can coordinate the communication between several smaller facilities and major hospital in large towns. This could also contain sophisticated diagnostic equipment such as; x-ray machine and CD4 counters, demanding additional power. Daily typical energy demand of this facility is in the range of $25-30 \mathrm{kWh}$.

The listing of various devices' inventories commonly found in major health facilities is provided in Table 2. The range of energy requirements signifies the peak power demand expected in a facility when most of the devices are operating simultaneously. However, some of the devices that required high-energy demand could be used intermittently while others are on stand-by power mode. All this needs to be considered while estimating average daily energy demand of any facility, most especially if the facility is equipped with batterypowered storage, for storing excess energy from the generator or RE sources to be used later.

A standard rural healthcare facility located in Iseyin district area of Oyo state, Nigeria has been used to create the load profile for five other hypothetical rural health clinics distributed across different climatic zones of Nigeria as earlier mentioned. This healthcare facility is made up of an emergency room, a doctor's consulting room, nurse/injection room, one male ward, one female ward, an operating room, a delivery room, and a laboratory. The total number of bed spaces in the clinic is 10. In this facility, electricity is required for: (1) Lighting for night hour's operations to support limited surgical procedures (such as; suturing and cesarean section) and to provide illumination in the surroundings at night. (2) Refrigerators, to keep cold chain vaccines, blood bank and other perishable medical supplies at desire temperature. (3) Basic laboratory equipment, including centrifuge, microscope, incubator, hematology mixer and hand-held power aspirator. Other appliances that require electrical power include; ceiling/wall fans, TV set, VCR, desktop computer and VHF radio communication equipment to aid communication with nearby referral centers. This rural clinic can be classified as category II rural health facility. The load descriptions and estimated demand of each facility are presented in Table 2. 
Table 2: The load description and estimated demand of the rural health clinic

\begin{tabular}{|c|c|c|c|c|c|c|c|}
\hline Load Description & Quantity & $\begin{array}{c}\text { Rated } \\
\text { Power(W) }\end{array}$ & $\begin{array}{c}\text { Total } \\
\text { Power } \\
(\mathrm{W})\end{array}$ & $\begin{array}{c}\text { Daytime } \\
\text { hour }(\mathbf{h} / \mathbf{d})\end{array}$ & $\begin{array}{c}\text { Night } \\
\text { hours } \\
\text { (h/d) }\end{array}$ & \begin{tabular}{|c|}
$\begin{array}{c}\text { Total on- } \\
\text { time } \\
(\mathbf{h} / \mathbf{d})\end{array}$ \\
\end{tabular} & $\begin{array}{c}\text { Total } \\
\text { Energy } \\
(\mathbf{k W h} / \mathbf{d})\end{array}$ \\
\hline \begin{tabular}{|l|} 
Lighting- CFL (indoor) \\
\end{tabular} & 8 & 15 & 120 & 2 & 6 & 8 & 0.96 \\
\hline Lighting-CFL (outdoor) & 6 & 40 & 240 & & 12 & 12 & 2.88 \\
\hline Ceiling/wall fan & 7 & 60 & 420 & 4 & 4 & 8 & 3.36 \\
\hline Blood bank refrigerator & 1 & 70 & 70 & 12 & 6 & 18 & 1.26 \\
\hline Vaccine Refrigerator & 1 & 60 & 60 & 12 & 6 & 18 & 1.08 \\
\hline Small Refrigerator & 1 & 300 & 300 & 5 & 5 & 10 & 3.00 \\
\hline Centrifuge & 1 & 242 & 242 & 3 & - & 3 & 0.73 \\
\hline Microscope & 2 & 20 & 40 & 6 & - & 6 & 0.24 \\
\hline Hematology Mixer & 1 & 28 & 28 & 4 & - & 4 & 0.11 \\
\hline Hematology Analyzer & 1 & 230 & 230 & 4 & - & 4 & 0.92 \\
\hline Lab Autoclave & 1 & 1500 & 1500 & 2 & - & 2 & 3.00 \\
\hline Incubator & 1 & 400 & 400 & 5 & - & 5 & 2.00 \\
\hline Oxygen Concentrator & 1 & 270 & 270 & 2 & - & 2 & 0.54 \\
\hline Ultrasound machine & 1 & 800 & 800 & 2 & - & 2 & 1.60 \\
\hline Vacuum Aspirator & 1 & 40 & 40 & 2 & - & 2 & 0.08 \\
\hline Suction Apparatus & 1 & 100 & 100 & 2 & - & 2 & 0.20 \\
\hline Desktop Computer & 1 & 150 & 150 & 5 & - & 5 & 0.75 \\
\hline TV set & 1 & 80 & 80 & 4 & 2 & 6 & 0.48 \\
\hline VCR & 1 & 20 & 20 & 2 & 2 & 4 & 0.08 \\
\hline Mobile Charger & 4 & 20 & 80 & 2 & 4 & 6 & 0.48 \\
\hline \multicolumn{8}{|l|}{ VHF Radio Receiver: } \\
\hline Standby & 1 & 2 & 2 & 24 & 12 & 36 & 0.07 \\
\hline Transmitting & 1 & 30 & 30 & 2 & 2 & 4 & 0.12 \\
\hline Total & & & 4,442 & & & 121 & 23.94 \\
\hline
\end{tabular}

\subsection{Hybrid system component modeling}

\subsubsection{PV module output power}

The system efficiency and output of a PV system vary for different day and different seasons of the year due to the changing local meteorological conditions. Therefore, adequate information on the daily and seasonal pattern of these meteorological data will enable energy planners to have a better understanding of the performance of a PV system. The PV system power output can be estimated as follows with respect to the effect of solar radiation and temperature [51, 52];

$$
P_{P V-g e n}=P_{m p-S T C} \times\left(G / G_{S T C}\right)\left[1+K_{T}\left(T_{c e l l}-T_{S T C}\right)\right]
$$

where $G_{S T C}$ is the solar radiation at standard test conditions obtained from manufacturer's datasheet and $\mathrm{G}$ is the solar radiation on inclined surface $\left(\mathrm{W} / \mathrm{m}^{2}\right) ; P_{m p-S T C}$, and $T_{S T C}$ are respectively the module rated power and temperature at standard test conditions obtained from manufacturer's datasheet. While $K_{T}$ is the module power temperature coefficient. $T_{\text {cell }}$ represents the PV module cell temperature given as [51, 52]; 


$$
T_{c e l l}=T_{a m b}+\left[\frac{(N O C T-20}{800}\right] \times G
$$

where, $T_{a m b}$ is the ambient temperature $\left({ }^{0} \mathrm{C}\right)$ and $N O C T$ is the normal cell temperature $\left({ }^{0} \mathrm{C}\right)$ usually specified in manufacturer datasheet. The overall generated power output of PV panels is obtained by multiplying panel output power $\left(P_{p v-g e n}\right)$ by the numbers of panel $\left(N_{p v}\right)$ considered.

$$
P_{p v(t)}=P_{p v-g e n} \times N_{p v}
$$

\subsubsection{Wind turbine model}

The principle of electricity generation from the wind is through conversion of kinetic energy of the wind into electrical energy. The wind turbine transforms the wind's kinetic energy in a rotor consisting of two or more blades mechanically coupled to an electric generator. The amount of energy received is enhanced by mounting the turbine on a tall tower. The wind to electrical power may be estimated by the following [14, 5255];

$$
P_{m}=\frac{1}{2} \rho A V^{3} C_{e}
$$

where $p, A, V$ and $C_{e}$ represent air density $\left(\mathrm{kg} / \mathrm{m}^{3}\right)$, turbine's swept area $\left(\mathrm{m}^{2}\right)$, wind speed $(\mathrm{m} / \mathrm{s})$, and the maximum power extraction efficiency of the wind generator, usually referred to as Bertz limit with peak value of about 0.59 respectively. This research study focuses on the use of the available renewable energy resources (i.e. wind and solar) at the selected locations with back-up storage system and diesel generatorystems. Therefore, 5 different small commercial wind turbine systems with rated power ranging from 1 to $5 \mathrm{~kW}$ have been considered in this study. The selected wind turbines and their specifications are presented in Table 3

Table 3: Specification of the five selected wind turbines [56]

\begin{tabular}{|l|c|l|l|l|l|}
\hline Parameter & Type 1 & Type 2 & Type 3 & Type 4 & Type 5 \\
\hline Model name & ABS 1000 & FDQ 3.0- & Windera & Wind Cruiser & SNT-50 \\
\hline Rated output & 1 & 1 & 3 & 3 & 5 \\
\hline Rated wind speed & 12 & 9 & 11 & 12 & 11 \\
\hline Cut-in speed & 2.5 & 2 & 3 & 2 & 2.5 \\
\hline Cut-off speed & 25 & 25 & 25 & 25 & 25 \\
\hline Rotor diameter & 1.8 & 3 & 4 & 4 & 4.26 \\
\hline Hub Height (m) & 17 & 17 & 12.5 & 17 & 18 \\
\hline Number of blade & 5 & 3 & 3 & 3 & 3 \\
\hline
\end{tabular}

\subsubsection{Diesel generator model}

Renewable energy systems are characterized by an intermittent output and are, therefore, integrated with a conventional power source to ensure reliable electricity supply to the health center. The complementary characteristic of the hybrid of renewable energy and non-renewable energy sources usually provides a better 
energy option compared to the single source systems. The fuel consumption of the diesel generator (DG), $F_{G}$ ( l/h) is modeled in HOMER as follows [52, 57]:

$$
F_{G}=B_{G} \times P_{G-\text { rated }}+A_{G} \times P_{G-o u t}
$$

where $P_{G \text {-rated }}$ is the nominal power of the diesel generator, $P_{G-o u t}$ is the output power, while $A_{G}$ and $B_{G}$ represents the coefficients of fuel consumption curve as defined by the user ( $1 / \mathrm{kWh})$. For efficient operation of the DG, it is recommended that partial loading, insufficient run-time to attain operating temperature and the excessive operation should be avoided. The optimum diesel generator operating range should be $70-89 \%$ [58, 59].

Renewable fraction (RF) is the total amount of power generated by the renewable energy sources compared to total power generation from the hybrid system. This can be express as [60];

$$
R F=\left(1-\frac{\sum P_{\text {diesel }}}{\sum P_{R E}}\right) \times 100 \%
$$

where $P_{\text {diesel }}$ is the power output of the diesel generator and $P_{R E}$ is the power output of the connected renewable energy sources, solar PV and wind in this case.

\subsubsection{Battery energy storage}

Battery capacity changes constantly in hybrid system due to the random behaviors of renewable energy resources (varying weather condition). At any time $t$, the battery capacity dependent on its previous state of charge (SOC), available energy from the RE sources in the HRES and the system load demand. The charging process of the battery occurs, whenever the energy output of PV modules and wind turbines is greater than the load demand. The battery charge capacity at this period can be described as [52, 61];

$$
C_{B}(t)=C_{B}(t-1) \cdot(1-\sigma)+\left[P_{T}(t)-\frac{P_{L}(t)}{\eta_{i n v}}\right] \times \eta_{B a t t}
$$

where $P_{L}(t)$ is the load demand, $\sigma$ is the battery self -discharging rate, $\eta_{i n v}$ and $\eta_{B a t t}$ are the inverter and battery efficiency respectively. While, $P_{T}(t)$ is the total power generated by the RE sources in the hybrid system at time $t$, given as:

$$
P_{T}(t)=N_{p v} P_{p v}+N_{w t} N_{w t}
$$

where $P_{p v}$ is the power output of PV panel, $P_{w t}$ is output power of the wind turbine, $N_{p v}$ and $N_{w t}$ are number of PV module and wind turbine respectively.

On a general note, whenever the total power generated by the RE sources is insufficient to meet the load demand the battery bank is in discharge mode. Therefore, the nominal capacity of battery and the charge quantity of the battery bank at this period can be respectively model as [52, 62]:

$$
C_{\text {Batt }}(W h)=\frac{P_{L}(t) \times A D}{\eta_{\text {Batt }} \times \eta_{\text {inv }} \times D o D}
$$




$$
C_{B}(t)=C_{B}(t-1) \cdot(1-\sigma)+\left[\frac{P_{L}(t)}{\eta_{i n v}}-P_{T}(t)\right] / \eta_{\text {Batt }}
$$

where $D o D$ is battery depth of discharge while, $A D$ is the chosen number of days of autonomy. During this

process, the battery discharge efficiency $\left(\eta_{\text {batt_disch }}\right)$ is equal to 1 , while it varies between (0.65-0.85) during charging period depending on the charging current. At any time $t$, the battery charge capacity is subject to the following constraints [52, 63]:

$$
S O C_{\min } \leq C_{B}(t) \leq S O C_{\max }
$$

where $S O C_{\max }$ and $S O C_{\min }$ are the maximum and minimum allow battery state of charge respectively. At this point, the maximum charge quantity of battery bank $\left(S O C_{\max }\right)$ takes the value of nominal capacity of battery bank $\left(C_{\text {Batt }}\right)$ and the minimum charge quantity of battery bank $\left(S O C_{\min }\right)$ is determined by the maximum depth of discharge.

$$
S O C_{\min }=(1-D O D) C_{B a t t}
$$

The operational lifetime of battery can be prolonged if $D O D$ is set within the range (30-50) \% depending on the manufacturer's specifications [51].

\subsection{Hybrid system optimal sizing}

In this study, hybrid optimization for multiple electric renewable (HOMER) softwere has been employed in the simulation, optimal sizing, sensitivity analysis as well as techno-economic evaluation of the proposed hybrid renewable energy system in the selected sites [60]. A comprehensive framework of optimal sizing and selection of different configurations of energy resources in each of the selected locations is shown in Figure 2. 


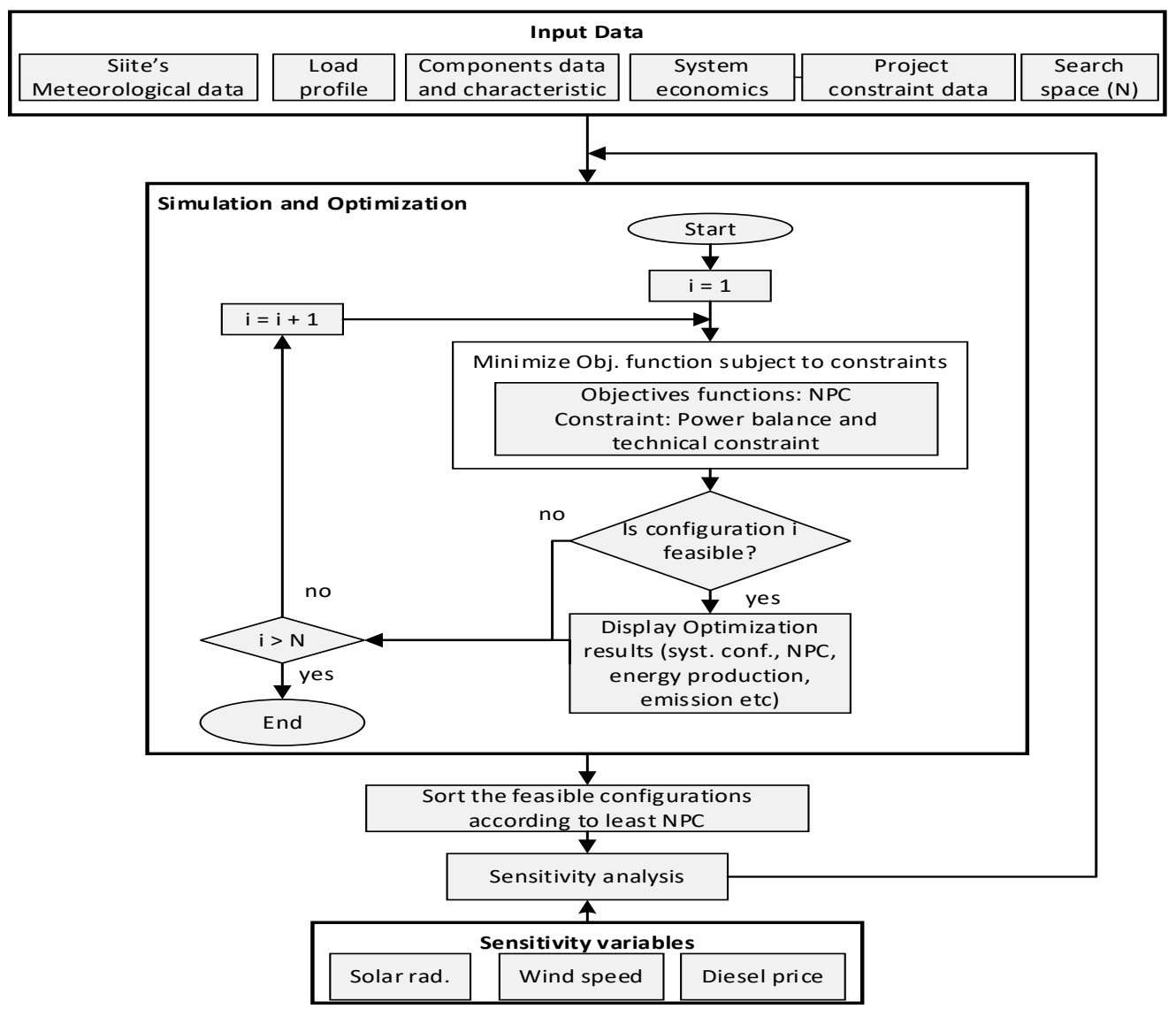

Figure 2: Comprehensive framework of HOMER optimal sizing procedure

\subsubsection{HOMER input data}

Six types of data are required by HOMER for simulation and optimization. These include meteorological data, load profile, equipment characteristics, search space, economic and technical data [60]. The following subsections described them in details.

\subsubsection{Meteorological data}

Hourly values of global solar radiation, wind speed and temperature data are not available at the selected sites, however the available monthly averages were synthesid to hourly data based on the algorithm provided for its conversion in HOMER [60]. These data serve as energy resources inputs to the software. HOMER utilized these data to compute power output of solar PV array and wind turbines.

\subsubsection{Clinics load profile}

The load profile of the respective rural health clinic in the considered sites is an essential input parameter to the HOMER model, since optimal sizing of different energy sources and the battery storage device depends on the load profile. As earlier mentioned, each of the rural healthcare facilities considered for this study is classified as a category II rural health clinic according to United States Agency for International Development [50], hence assumed to have identical load profile. Therefore, the computation of the energy demand of each equipment presented in Table 2 with their expected operating hours known as watt-hour demand is shown in 
Figure 3 for the rural health facilities in the selected sites. Based on this profile, average daily energy demand and the peak load are found to be approximately $23.9 \mathrm{kWh}$ and $3.75 \mathrm{~kW}$ respectively.

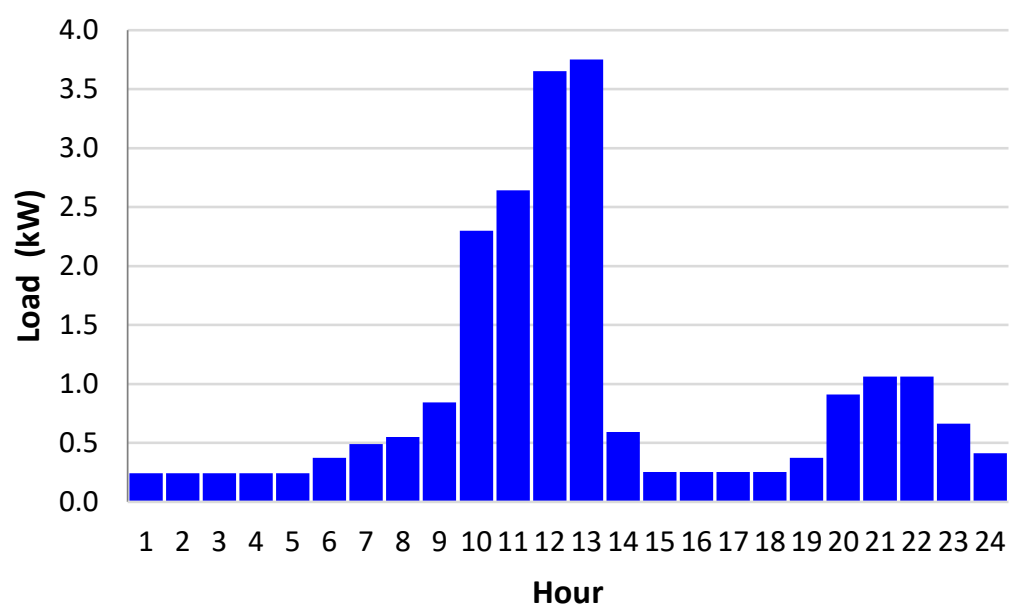

Figure 3: Daily load profile of the selected healthcare facilities

It should be noted that, not all the equipment presented in Table $\mathbf{2}$ are expected to operate simultaneously, because each has specific daily hours of operation. Major load occurs during the daytime (9am to $1 \mathrm{pm}$ ) and nighttime (7-10pm). This is due to the nature of the rural settings where the dwellers visit the clinic in the morning or late evening after the day work. Based on this variation, a day-to-day random noise of $10 \%$ and hour-to-hour random variability of $15 \%$ is specified in HOMER. This is done to check the effect of the daily and hourly load variation on the hybrid system configuration to avoid underestimating the peak load demand of the proposed system.

\subsubsection{Hybrid system components data}

Assumptions regarding components pricing and sizing as adopted in the proposed hybrid system, are expressed below:

a) A 36-cell mono-crystalline PV module with rated capacity $250 \mathrm{~W}_{\mathrm{p}}$, manufactured by Canadian Solar Company was selected for simulation. The current PV module price in Nigeria's market is $\$ 3,160 / \mathrm{kW}$, while the installation cost is $\$ 40 / \mathrm{kW}$ [64]. Therefore, the capital cost and replacement cost of $1 \mathrm{kWp}$ PV array were taken as $\$ 3200$ and $\$ 3000$ respectively. The lifetime of PV arrays was taken as 25 years. The de-rating factor that accounts for losses due to temperature effects, dirt from the PV module's surface and wiring losses was considered as $80 \%$, and the ground reflection of the modules were taken as 20\%[51]. Different sizes of PV arrays were considered to obtain the optimal size for each site.

b) Three different wind turbine models $(1 \mathrm{~kW}, 3 \mathrm{~kW}$ and $5 \mathrm{~kW})$ with technical specifications given in Table 3 is considered for the hybrid system configurations in each site. The initial cost, replacement cost and cost of maintenance for each type are specified. In order to find an optimal size, different sizes of each model were analyzed. The operational lifetime of the turbines varies between 15 to 20 years.

c) The initial cost of a $1 \mathrm{~kW}$ AC diesel generator is $\$ 200$, with a replacement cost of $\$ 200$ and maintenance cost of $\$ 0.05 / \mathrm{hr}$ [64]. Two different sizes (5kW and $7.5 \mathrm{~kW}$ ) of diesel generator was considered. The operating lifetime of a diesel generator was taken as 15,000 hours with a minimum load ratio of $25 \%$. 
d) A bi-directional converter is added to maintain the flow of energy between the alternating current (AC) and direct current (DC) components. It functions as a rectifier when it converts AC to DC, and as an inverter on the other way around. The initial capital and replacement cost of the converter used for this study were taken as $\$ 245 / \mathrm{kW}$ and $\$ 245 / \mathrm{kW}$ respectively [64]. The operational and maintenance cost is taken as $\$ 10 /$ year [51]. The efficiency of the converter is $90 \%$ and $85 \%$ for the rectifier, while the lifetime was taken as 10 years [65]. Different sizes of converters were considered during the analysis.

e) Trojan L16P type battery with rated 6V nominal voltage, 2kWh nominal capacity, 1,075 throughput, $85 \%$ round trip efficiency and $30 \%$ minimum state of charge is considered for this study. The initial cost of one unit is $\$ 330$ [64]. Replacement and operational maintenance costs were assumed as $\$ 300$ and $\$ 10 / y e a r$ respectively [62]. In order to find an optimal configuration, the battery bank was assumed to contain a different number of batteries. Each battery string contains 10 batteries, and the lifetime energy of each battery is $1,075 \mathrm{kWh}$ throughput [64].

\subsubsection{System economic parameters}

In HOMER, the system life-cycle cost is represented by total net present cost (NPC). The NPC is a composite of system component's initial capital cost, replacement cost, annual operating and maintenance cost as well as fuel costs[60].

$$
N P C_{T o t}=\frac{C_{a n n, T o t}}{C R F}
$$

where, $C R F$ is capital recovery factor, and can be evaluated in terms of interest rate (i) and project lifetime (n) as [60];

$$
C F R=\frac{i(1+i)^{n}}{(1+i)^{n}-1}
$$

However, in a PV/wind/diesel/battery hybrid system, total annualized cost of the entire hybrid system can be represented as;

$$
\begin{aligned}
C_{a n n, T o t}=\sum_{N=1}^{N_{p v}} C_{a n n, p v}+\sum_{N=1}^{N_{w t}} C_{a n n, w t}+\sum_{N=1}^{N_{b a t t}} C_{a n n, D G}+\sum_{N=1}^{N_{b a t t}} C_{a n n, b a t} \\
+\sum_{N=1}^{N_{c o n v}} C_{a n n, c o n v}
\end{aligned}
$$

where, $N_{p v}, N_{w t}, N_{D G}, N_{b a t}$, and $N_{c o n v}$ are numbers of PV modules, wind turbine, diesel generator, battery and converter respectively. While $C_{a n n, p v}, C_{a n n, w t}, C_{a n n, D G}, C_{a n n, b a t}$ and $C_{a n n, c o n v}$ are total annualized cost for each components (PV modules, wind turbine, diesel generator battery and converter) as computed from:

$$
C_{a n n}=C_{a n n, c a p .}+C_{a n n, r e p .}+C_{a n n, O \& M}
$$

In this study, the project lifetime is considered 25 years and the current annual interest rate in the country is $11 \%$, while the inflation rate stands at $15.1 \%$ [66]. These economic parameters are needed to compute the CRF. Thereafter, HOMER uses the CRF to compute the NPC for various system configurations. HOMER aims to minimize the total net present cost (NPC) and cost of electricity (COE) by finding the optimal system 
configuration that matches the load demand and satisfies these constraints. It should be noted that all economic factors considered in HOMER are calculated in constant dollar (US\$) terms. As at the time of this research work, USD1 is equivalent to N362.25 Nigeria's naira.

\subsubsection{System technical constraints}

Constraints are pre-determined conditions the systems must fulfil in HOMER to ensure realistic optimal solution; otherwise, HOMER neglects those systems that do not content the defined constraints. In this study, the maximum renewable fraction (RF) ranges from $0-100 \%$ are considered, while maximum unserved energy is assumed to be $0 \%$. In addition, $0 \%$ maximum annual capacity shortage was considered in the simulation. The maximum allowable capacity shortage factor is a ratio of the total capacity shortage and the total annual electric load, which represent the amount of time to which the system could not meet the load demand and its reserves. However, this is not the case in this system due to the nature of the load and the intended application which requires $100 \%$ reliability. Hourly load variation of $10 \%$ is considered in the simulation with operating reserve accounting for sudden spikes in the system. In the case of PV panel's output, $25 \%$ reserve is considered this is due to its inherent dependence on solar irradiance leading to unpredictable output.

\subsubsection{System control/energy management}

System control parameter defines how the system models the operation of battery and generators in the hybrid system. A dispatch strategy is a set of rules that controls the operations of the diesel generator and the battery bank. Two types of dispatch strategies are available in HOMER, namely; load following and cycle charging [52]. In the load-following strategy, a generator produces power that is sufficient only to serve the load and does not charge the battery bank. Conversely, in the cycle-charging strategy, the generator operates at its maximum rated capacity to serve the load and charges the battery bank with the excess power. In the proposed system, cycle-charging strategy has been considered. This means that HOMER will simulate each system using this dispatch strategy and subsequently determine the optimal configuration.

In a multi-source hybrid energy system, an overall control/energy management system to manage the energy flow within the various connected energy source and the load is essential. To this aim, an energy management/control system has been designed for the optimization of the energy flows among the various energy sources and the load. The control strategy is designed to operate in different modes according to the flowchart in Figure 4. In this control system, priority is given to RE sources to supply the load, that means, under normal operating condition the power output of solar PV $\left(P_{p v}\right)$ and wind turbine $\left(P_{w t}\right)$ will supply the load while excess energy will be used to charge the battery until maximum state of charge $\left(S O C_{\max }\right)$ is reached. Any further excess energy can be used by dump load. In the case of insufficient energy from either the RE sources or the battery to supply the load, a conventional diesel generator will be operated automatically to supply the load and charge the battery. The supervisory control is responsible for switching from one operating mode to another depending on the atmospheric conditions, the load demand, and the battery SOC. The decision to operate any of the energy sources and to charge/discharge the battery takes place every hour upon the energy balance computation. 


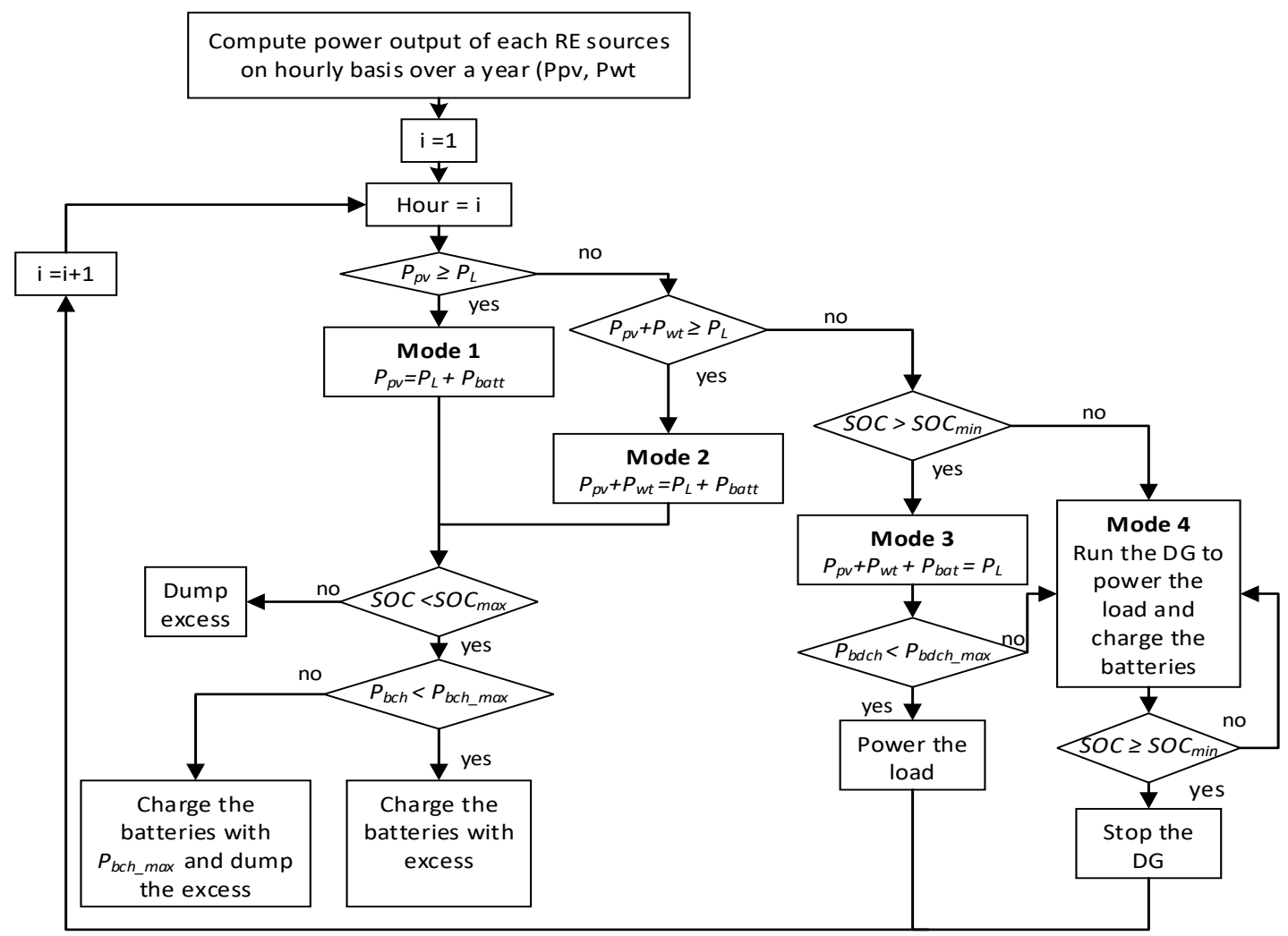

Figure 4: Flowchart of the energy management system adopted in HOMER

\subsubsection{Hybrid system optimization}

Assessment of optimal system configurations is carried out by optimizing the objective function of total life-cycle cost of the entire hybrid system represented in Figure 5.

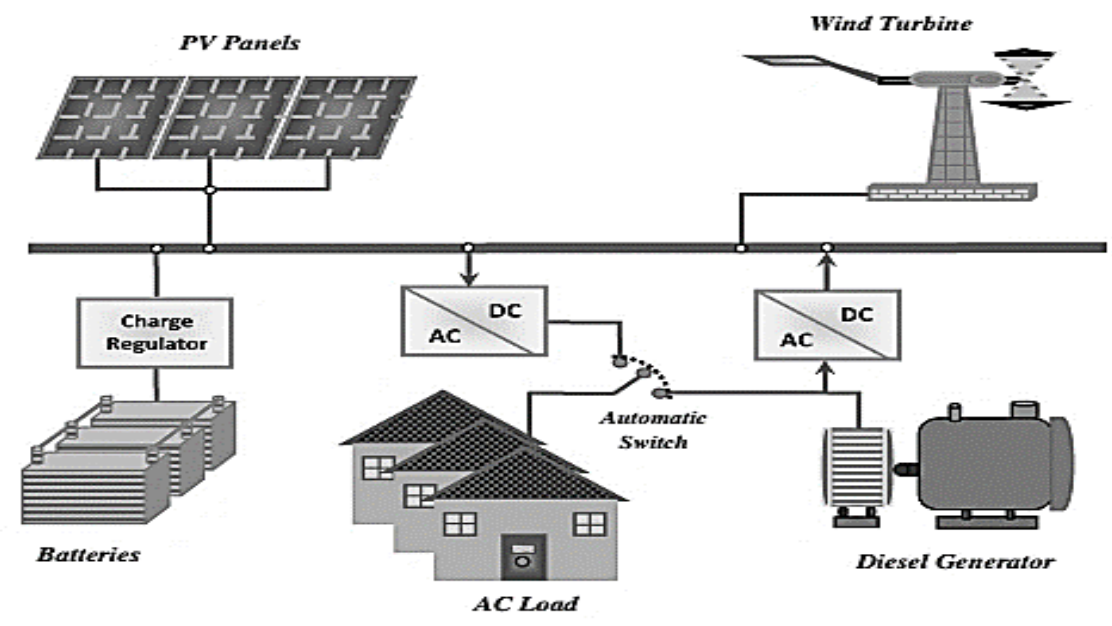

Figure 5: The proposed hybrid system configuration 
The optimal value of decision variable is determined during the optimization process. The decision variables considered for this study are based on the available resources and the load demand. This includes; size of PV panel, number of wind turbine, number of battery and the size of converter. The objective function is given as:

Minimize:

$$
C_{a n n}=\sum_{j}\left(C_{\text {ann,cap. }}+C_{\text {ann,rep. }}+C_{a n n, O \& M}\right)
$$

where $j$ is the number of units of the system component (solar panel, wind turbine, diesel generator, battery

and converter). $C_{a n n, c a p,}, C_{a n n, r e p}$. and $C_{a n n, O \& M}$ is the annualized capital, replacement, operating and maintenance cost of each system components. The equation can be rewriten as:

$$
C_{\text {ann }}(j)=N \times\left\{\left[C_{\text {ann,cap. }}+C_{\text {ann,rep. }} \times K_{j}\left(i, L_{j}, y_{j}\right)\right] \times C R F(i, n)+C_{\text {ann }, 0 \& M}\right\}
$$

where $N$ is the number of components/capacity, CFR is capital recovery factor earlier described in Equation (19), where $n$ is project lifetime and $i$ is the real interest rate, which is a function of nominal interest rate $\left(i_{\text {nom }}\right)$ and annual inflation rate $(f)$ defined as;

$$
i=\frac{i_{\text {nom }}-f}{i+f}
$$

$K$ is single payment present worth factor given as;

$$
K_{j}\left(i, L_{j}, y_{j}\right)=\sum_{x=1}^{y_{j}} \frac{1}{(i+1)^{x \times L_{j}}}
$$

where $L$ and $y$ are respectively the useful lifetime and the number of replacement of component during the project lifetime $(n)$.

For each search space in the optimization process, the objective function is minimized subject to the set constraint. The constraints include; energy balance constraint (loss of power supply probability), battery charging and discharging constraints and generator technical constraints.

\section{RESUlts AND Discussion}

This section presents the results of various sections of the study earlier highlighted. A discussion of each of these results is also included.

\subsection{Renewable energy resources assessment}

The potentials of major renewable energy sources (wind and solar) in selected locations across the six geopolitical regions of the country, based on long-term daily meteorological data spanning between 18 and 39 years have been assessed, and the result obtained is discussed in the following section;

\subsubsection{Solar radiation on horizontal surfaces}

Figure 6 shows the mean monthly radiation for each site. 


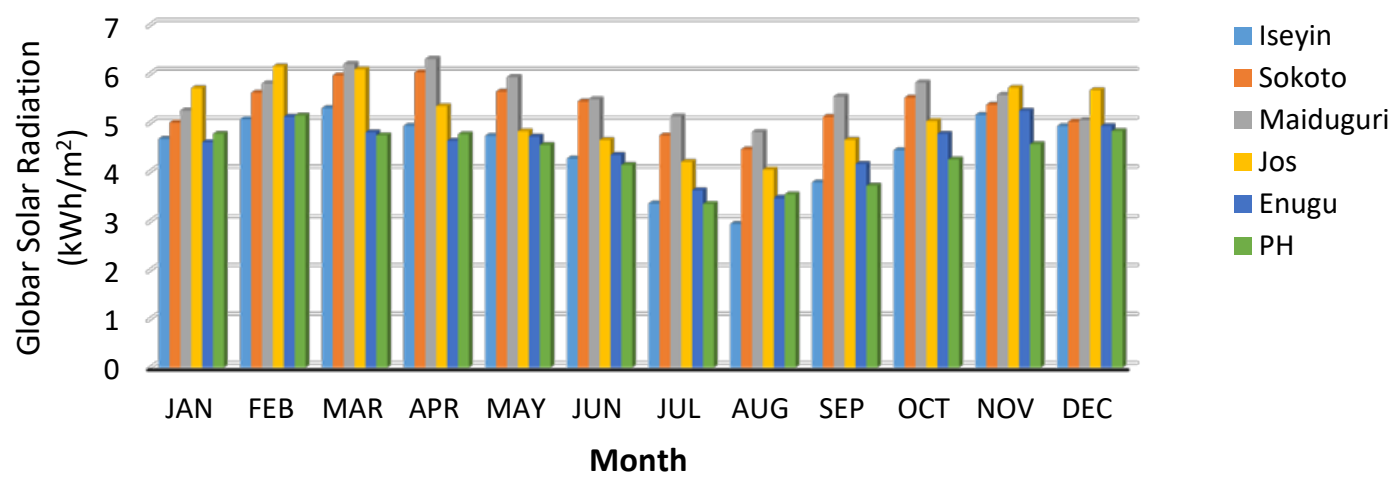

Figure 6: Mean monthly radiation on horizontal plane

Maiduguri is observed to have the highest global solar radiation among the selected sites, while the least occurred at Port Harcourt. The maximum and minimum values for Maiduguri were obtained in April and August respectively, while the maximum and minimum value was obtained in December and July respectively in Port Harcourt. Values obtained for the remaining sites can be seen on the figure. It can further be observed from obtained results, that all locations have higher levels of horizontal global solar radiations during the dry season months (October to April). This shows that the dry season is the best season for solar energy harvesting as ealier reported in ref [49]. During the rainy season (April to September), the amount of total radiation reduce notably compare with others.

\subsubsection{Wind speed frequency distribution}

The annual probability density and cumulative distribution functions obtained for wind speed at the selected locations are shown in Figures 7 and 8 respectively.

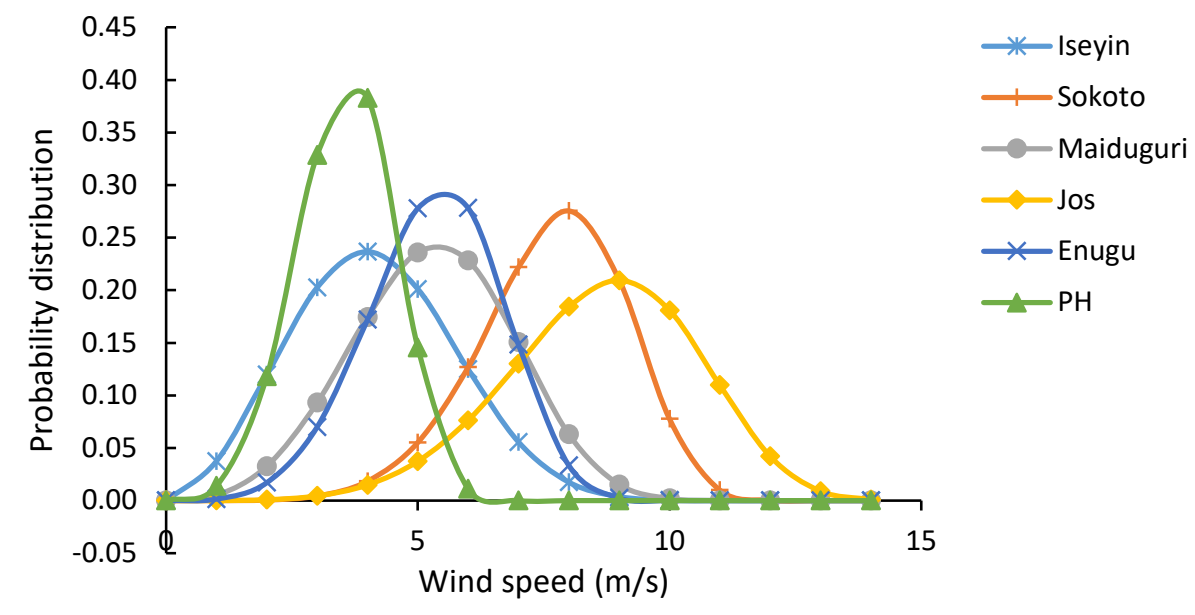

Figure 7: Probability density function of the selected sites

It can be observed from Figure 7 that, the peak of the density functions of all the sites skewed towards the higher values of mean wind speed; the peak further indicates the most frequent velocity. The most frequent 
wind speeds of 9.0, 8.0 and $6.0 \mathrm{~m} / \mathrm{s}$ are expected in Jos, Sokoto, and Maiduguri respectively, while the least occurs in Port-Harcourt at $3.5 \mathrm{~m} / \mathrm{s}$.

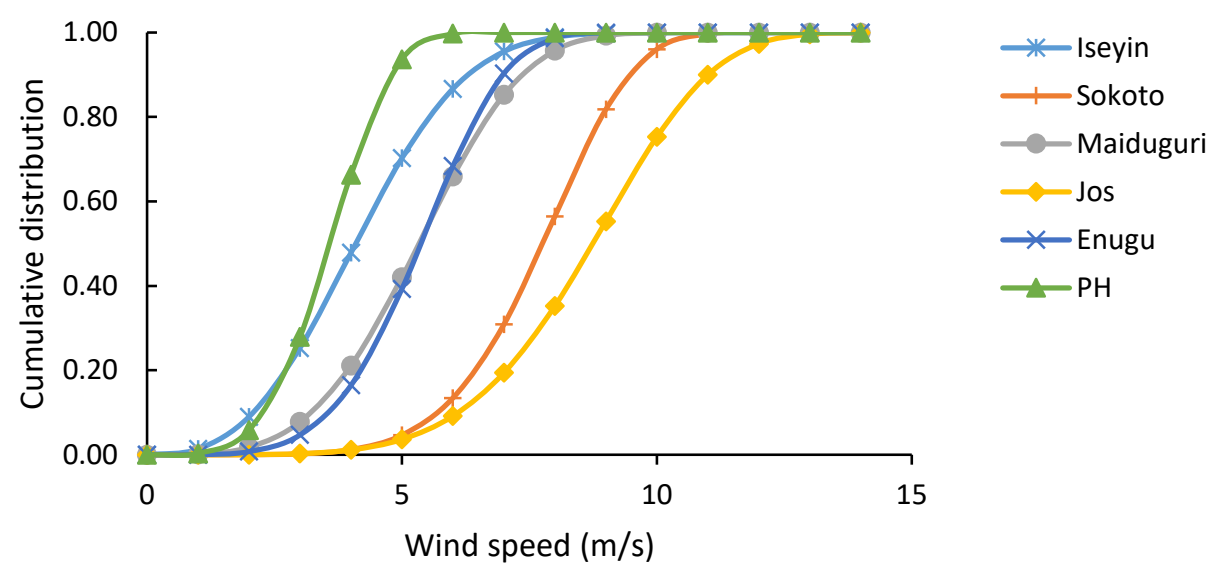

Figure 8: Cumulative density function of the selected site

It can further be observed that Jos has the highest spread of wind speeds among the locations. Similar trend is observed in the cumulative probability distributions of wind speed in all the locations as shown in Figure 8. For wind speeds greater or equal to $3.0 \mathrm{~m} / \mathrm{s}$ cut-in wind speed, Sokoto, Jos, Enugu, Maiduguri, Port Harcourt, and Iseyin have frequencies of about 99.8, 99.7, 94.5, 90.3, 65.9 and 64.3\% respectively. All the sites have monthly peak frequency range between 26 and 40.6\%, and having 26, 28.5, 35.3, 37.3, 40.2 and $40.6 \%$ for Iseyin, Jos, Maiduguri, Enugu, Sokoto and Port Harcourt respectively. Iseyin has its peak frequency at $4 \mathrm{~m} / \mathrm{s}$ in December, Jos at $10 \mathrm{~m} / \mathrm{s}$ in May, Maiduguri in September at $5 \mathrm{~m} / \mathrm{s}$, Enugu in October at $5 \mathrm{~m} / \mathrm{s}$, Sokoto at $7 \mathrm{~m} / \mathrm{s}$ in August and Port Harcourt in January at $4 \mathrm{~m} / \mathrm{s}$. This comfirmed the earlier report from refs [46, 47] that the country has a low to moderate wind regime, with low wind speeds in the south, excluding the coastal regions; while the wind speeds is considered reasonable good in the northern region.

\subsubsection{Mean wind speed and mean power density}

The monthly mean wind speeds at $10 \mathrm{~m}$ height, wind power density for the selected sites are presented in Table 4. The monthly mean wind speed varies between $3.48 \mathrm{~m} / \mathrm{s}$ in November and $4.71 \mathrm{~m} / \mathrm{s}$ in April for Iseyin. The shape parameter $k$ varies between 2.02 and 2.92, while the scale parameter $c$ lies between 3.92 and $5.27 \mathrm{~m} / \mathrm{s}$. Power density varies between $46.48 \mathrm{~W} / \mathrm{m}^{2}$ in October and $89.69 \mathrm{~W} / \mathrm{m}^{2}$ (March). The annual mean wind speed and wind power density are found to be $4.16 \mathrm{~m} / \mathrm{s}$ and $85.64 \mathrm{~W} / \mathrm{m}^{2}$ respectively. According to the wind power classification scheme [67] of Pacific Northwest Laboratory presented in Table 5, the monthly mean and the annual mean power density for Iseyin falls into Class 1 . This is considerd poor and may only be suitable for battery charging, water pumping and other small wind power applications.

The minimum and maximum values of the monthly mean wind speeds are found to be 5.81 and $9.03 \mathrm{~m} / \mathrm{s}$ respectively for Sokoto. The monthly mean shape parameter $(k)$ has values between 3.17 and 9.94 , while the scale parameter $c$ is between 6.30 and $9.72 \mathrm{~m} / \mathrm{s}$. The monthly mean wind power density varies from 134.79 $\mathrm{W} / \mathrm{m}^{2}$ in September to $494.61 \mathrm{~W} / \mathrm{m}^{2}$ in January. However, the annual mean power density for this site stand at $515.40 \mathrm{~W} / \mathrm{m}^{2}$, which makes the site to ranked at Class 7 and thus suitable for grid-connected wind power applications. In the case of Maiduguri, the minimum and maximum values of the monthly mean wind speeds are $4.49 \mathrm{~m} / \mathrm{s}$ (in September) and $6.10 \mathrm{~m} / \mathrm{s}$ (in March) respectively. 
The monthly mean power density varies from $63.90 \mathrm{~W} / \mathrm{m}^{2}$ in September to $173.38 \mathrm{~W} / \mathrm{m}^{2}$ in March; with annual mean power density for $171.40 \mathrm{~W} / \mathrm{m}^{2}$, the site is ranked Class 3 .

Table 4: Monthly and annual mean variation of wind speed and power density in the selected sites

\begin{tabular}{|c|c|c|c|c|c|c|c|c|c|c|c|c|}
\hline \multirow[t]{2}{*}{ Site } & \multicolumn{2}{|c|}{ Iseyin } & \multicolumn{2}{|c|}{ Sokoto } & \multicolumn{2}{|c|}{ Maiduguri } & \multicolumn{2}{|c|}{ Jos } & \multicolumn{2}{|c|}{ Enugu } & \multicolumn{2}{|c|}{ Port Harcout } \\
\hline & $\begin{array}{c}\mathbf{V} \\
(\mathbf{m} / \mathbf{s})\end{array}$ & $\begin{array}{c}\mathbf{P} \\
\left(W / \mathbf{m}^{2}\right)\end{array}$ & $\begin{array}{c}\mathbf{V} \\
(\mathrm{m} / \mathrm{s})\end{array}$ & $\begin{array}{c}\mathbf{P} \\
\left(\mathrm{W} / \mathbf{m}^{2}\right)\end{array}$ & $\underset{(\mathbf{m} / \mathbf{s})}{\mathrm{V}}$ & $\begin{array}{c}\mathbf{P} \\
\left(\mathrm{W} / \mathbf{m}^{2}\right)\end{array}$ & $\begin{array}{c}V \\
(\mathbf{m} / \mathbf{s})\end{array}$ & $\begin{array}{c}\mathbf{P} \\
\left(\mathrm{W} / \mathbf{m}^{2}\right)\end{array}$ & $\underset{(\mathbf{m} / \mathbf{s})}{\mathrm{V}}$ & $\begin{array}{c}\mathbf{P} \\
\left(\mathrm{W} / \mathbf{m}^{2}\right)\end{array}$ & $\begin{array}{c}\mathrm{V} \\
(\mathbf{m} / \mathbf{s})\end{array}$ & $\begin{array}{c}\mathbf{P} \\
\left(W / \mathbf{m}^{2}\right)\end{array}$ \\
\hline Jdil & 21 & 4 & 8.95 & 494.61 & 4.94 & 22 & 9.15 & 603.3 & 62 & & & \\
\hline Feb & 36 & 47 & 8.63 & 469.62 & 5.90 & 159.9 & 9.16 & 544.5 & 66 & & & .98 \\
\hline Mar & & & & & & 173.3 & 9.04 & 488.0 & & & & \\
\hline Apr & 71 & & 7.5 & & 5.80 & 142.7 & 8.95 & 538.0 & & & & \\
\hline May & & & & & & 146.7 & 9.01 & 474.1 & & & & \\
\hline Jun & 4.35 & 74.12 & 9.03 & 46 & 6.06 & 173.3 & 8.56 & 430.1 & 1 & & 7 & 36.44 \\
\hline Jul & & & & & & 153.2 & 8.65 & 422.9 & & & & \\
\hline Aug & .26 & 6 & 6.23 & 15 & 4.62 & 74.55 & 8.23 & \begin{tabular}{|l|}
371.9 \\
\end{tabular} & + & & 3.93 & 44.29 \\
\hline Sep & & & 5.81 & & 4.49 & 63.90 & 7.15 & 260.8 & & & & 34.40 \\
\hline Oct & 3.61 & 46.48 & 6.02 & 179 & 4.5 & 72.12 & 7.64 & 322.5 & 4.56 & & 3.19 & 25.60 \\
\hline Nov & 3.48 & 48.18 & 7.50 & & 5.10 & 103.8 & 8.54 & 464.1 & 4.12 & & 2.91 & 19.52 \\
\hline Dec & 3.91 & 50.54 & 7.86 & 327.40 & 4.68 & 81.31 & 9.36 & 581.1 & 4.95 & 97.52 & 2.86 & 20.35 \\
\hline Ann. & 4.16 & 85.46 & 7.63 & 515.4 & 5.309 & 171.4 & 8.62 & 741.0 & 5.31 & 172.7 & 3.56 & 54.07 \\
\hline
\end{tabular}

Table 5: Wind power classification

\begin{tabular}{|r|c|c|l|}
\hline $\begin{array}{c}\text { Power } \\
\text { Class }\end{array}$ & $\begin{array}{c}\text { Average wind speed } \\
(\mathrm{m} / \mathrm{s}) \text { at } 10 \mathrm{~m}\end{array}$ & $\begin{array}{c}\text { Power density } \\
\left(\mathrm{W} / \mathrm{m}^{2}\right) \text { at } 10 \mathrm{~m}\end{array}$ & Remarks \\
\hline 1 & $0-4.4$ & $0<P \leq 100$ & Poor \\
\hline 2 & $4.4-5.1$ & $100<P \leq 150$ & Marginal \\
\hline 3 & $5.1-5.6$ & $150<P \leq 200$ & Fair \\
\hline 4 & $5.6-6.0$ & $200<P \leq 250$ & Good \\
\hline 5 & $6.0-6.4$ & $250<P \leq 300$ & Excellent \\
\hline 6 & $6.4-7.0$ & $300<P \leq 400$ & Outstanding \\
\hline 7 & $>7.0$ & $400<P \leq 1000$ & Super \\
\hline
\end{tabular}

The minimum and maximum values of the monthly mean wind speeds varied from 7.15 (September) to $9.36 \mathrm{~m} / \mathrm{s}$ (December) respectively in Jos. The monthly mean shape parameter $k$ ranges between 3.50 and 7.55, while the scale parameter $c$ is from 7.82 and $10.23 \mathrm{~m} / \mathrm{s}$. Monthly mean wind power density varies from 260.83 $\mathrm{W} / \mathrm{m}^{2}$ in September to $603.38 \mathrm{~W} / \mathrm{m}^{2}$ in January. The average annual power density stands at $741.20 \mathrm{~W} / \mathrm{m}^{2}$, making the site to fall in Class 7 of the wind power classification. This classification places Jos on a high potential site for large-scale grid-connected wind turbine applications. The wind speed characteristics of Enugu and Port-Harcourt are also shown Tables 3.4 and 3.5. The minimum and maximum values of wind speed are 4.12 and $6.30 \mathrm{~m} / \mathrm{s}$ respectively for Enugu whereas they exist as 2.86 and $3.98 \mathrm{~m} / \mathrm{s}$ in Port-Harcourt for the minimum and maximum. Considering the wind power density, the dry season is found to be the windiest season for both sites. Monthly wind power ranges from $53.50 \mathrm{~W} / \mathrm{m}^{2}$ in November to $169.32 \mathrm{~W} / \mathrm{m}^{2}$ in March at Enugu, while it varies from 19.52 to $44.29 \mathrm{~W} / \mathrm{m}^{2}$ in November and August respectively in Port-Harcourt. With the wind power classification in Table 5, Enugu falls under Class 3, and Port-Harcourt in Class 1, thereby making the Enugu to be fairly considered for wind power applications and Port-Harcourt poor. 


\subsubsection{Wind energy density}

Hourly measured wind data obtained from the respective meteorological stations in each site is divided into bins (0-1, 1-2, 2-3 and so on) and the duration of occurrence of the data at any particular bin is calculated from the obtained wind speed data as shown in Figure 9. Thereafter, the probability density function (PDF) for each wind speed range, energy available in the wind at each range and the total energy expected in each site is calculated. The summary of the annual energy density at the selected sites is presented in Table 6 using the available data and the Weibull function.

Table 6: Summary of annual energy density at the selected sites using the available data and Weibull function

\begin{tabular}{|l|l|c|c|c|c|c|c|}
\hline \multirow{2}{*}{ Method } & Parameter & Iseyin & Sokoto & Maiduguri & Jos & Enugu & Port Harcourt \\
\hline \multirow{2}{*}{ Data } & Power $\left(\mathrm{W} / \mathrm{m}^{2}\right)$ & 85.33 & 516.57 & 172.45 & 741.22 & 172.38 & 54.58 \\
\cline { 2 - 8 } & Energy $\left(\mathrm{kWh} / \mathrm{m}^{2}\right)$ & 747.32 & 4525.14 & 1510.67 & 6393.12 & 1510.0 & 478.16 \\
\hline \multirow{2}{*}{ Weibull } & Power $\left(\mathrm{W} / \mathrm{m}^{2}\right)$ & 85.46 & 515.41 & 171.35 & 741.22 & 172.73 & 54.07 \\
\cline { 2 - 8 } & Energy $\left(\mathrm{kWh} / \mathrm{m}^{2}\right)$ & 748.66 & 4514.97 & 1510.03 & 6491.33 & 1513.1 & 473.44 \\
\hline
\end{tabular}
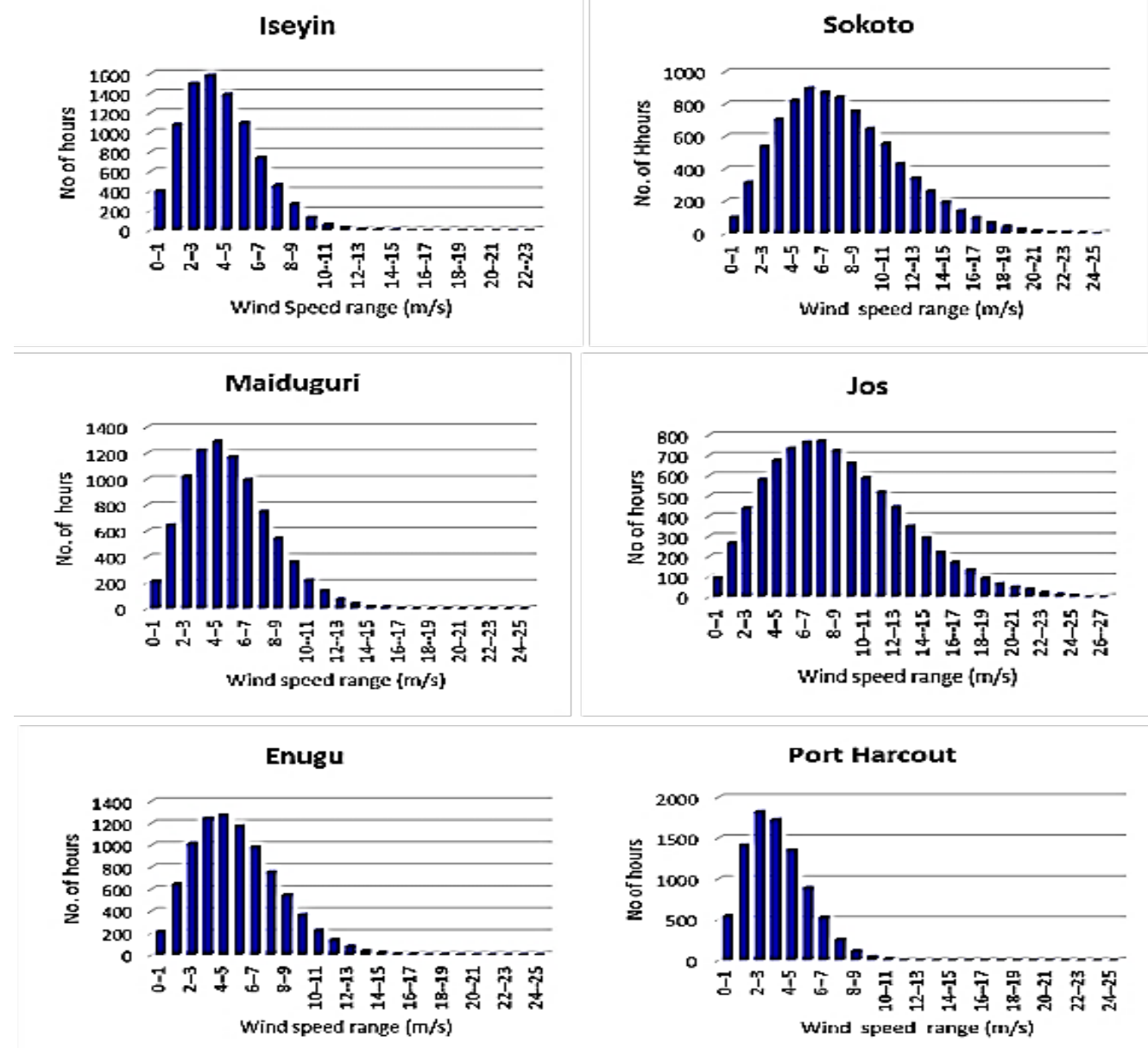

Figure 9: Numbers of hours of occurrence of wind speed in each bin for the selected sites 
It can be observed from Figure 9 that, Jos and Sokoto had the highest spread of wind speeds among the selected, this has contributed to high energy density the two sites. Annual energy density of 478.16 and 747.30 kWh observed in Port Harcourt and Iseyin site respectively. This is considered too low for profitable wind energy applications, unless for water pumping or battery charging purpose.

\subsection{Optimum system configurations}

Table 7 presents the optimal results in the selected sites in terms of number and sizes of constituent hybrid system components in each configuration, initial capital cost, total NPC, cost of energy production, the amount of liter of fuel consumed by diesel generator and finally the renewable faction of each configuration.

Table 7: Comparison of various system configurations in the selected sites

\begin{tabular}{|c|c|c|c|c|c|c|c|c|c|c|c|}
\hline \multirow[b]{2}{*}{ Sites } & \multirow{2}{*}{\begin{tabular}{|l|} 
System \\
Configuration \\
System Configuration
\end{tabular}} & \multicolumn{5}{|c|}{ Components size } & \multicolumn{3}{|c|}{ Economics } & \multirow{2}{*}{$\begin{array}{c}\text { Fuel } \\
\text { Consp } \\
(\mathrm{L} / \mathrm{yr} .)\end{array}$} & \multirow[b]{2}{*}{$\begin{array}{l}\mathrm{RF} \\
(\%)\end{array}$} \\
\hline & & $\begin{array}{c}\mathrm{PV} \\
(\mathrm{kW})\end{array}$ & $\begin{array}{l}\text { Wind } \\
(\mathrm{kW})\end{array}$ & $\begin{array}{c}\text { Diesel } \\
(\mathrm{kW})\end{array}$ & $\begin{array}{l}\text { Batt. } \\
\text { (no.) }\end{array}$ & $\begin{array}{c}\text { Conv. } \\
(\mathrm{kW})\end{array}$ & $\begin{array}{c}\text { Initial } \\
\text { cap (\$) }\end{array}$ & $\begin{array}{c}\text { Total } \\
\text { NPC (\$) }\end{array}$ & $\begin{array}{c}\mathrm{COE} \\
(\$ / \mathrm{kWh})\end{array}$ & & \\
\hline \multirow[t]{2}{*}{ Iseyin } & PV-Wind-Diesel-Batt. & 6 & 1 & 5 & 24 & 5 & 35,070 & 102,949 & 0.311 & 425 & 84 \\
\hline & PV-Diesel-Battery & 6 & - & 5 & 24 & 5 & 29,345 & 110,717 & 0.334 & 791 & 71 \\
\hline \multirow[t]{2}{*}{ Sokoto } & PV-Wind-Diesel-Batt. & 4 & 2 & 5 & 8 & 5 & 29,115 & 71,210 & 0.215 & 142 & 95 \\
\hline & Wind-Diesel -Battery & - & 3 & 5 & 16 & 5 & 24,680 & 81,358 & 0.246 & 253 & 91 \\
\hline \multirow[t]{2}{*}{ Maiduguri } & PV- Wind-Diesel-Batt. & 6 & 1 & 5 & 16 & 5 & 32,430 & 81,545 & 0.246 & 128 & 96 \\
\hline & PV-Diesel-Battery & 6 & - & 5 & 24 & 5 & 29,345 & 90,428 & 0.273 & 307 & 89 \\
\hline \multirow[t]{2}{*}{ Jos } & PV- Wind-Diesel-Batt. & 4 & 2 & 5 & 8 & 5 & 29,115 & 68,585 & 0.207 & 113 & 96 \\
\hline & Wind-Diesel -Battery & - & 3 & 5 & 16 & 5 & 24,680 & 77,773 & 0.235 & 243 & 91 \\
\hline \multirow[t]{2}{*}{ Enugu } & PV- Wind-Diesel-Batt. & 5.5 & 2 & 5 & 16 & 5 & 36,555 & 89.991 & 0.272 & 154 & 95 \\
\hline & PV-Diesel-Battery & 6 & - & 5 & 24 & 5 & 29,345 & 109,373 & 0.330 & 758 & 72 \\
\hline \multirow{2}{*}{$\begin{array}{l}\text { Port } \\
\text { Harcourt }\end{array}$} & PV-Diesel-Battery & 7 & - & 5 & 24 & 5 & 32,545 & 106,870 & 0.323 & 554 & 80 \\
\hline & PV-Wind-Diesel-Batt. & 7 & 2 & 5 & 16 & 5 & 44,240 & 108,920 & 0.329 & 177 & 94 \\
\hline \multirow[t]{2}{*}{ All sites } & Diesel-Battery & - & - & 5 & 8 & 1 & 3,885 & 175,199 & 0.529 & 3,359 & 0 \\
\hline & Diesel alone & - & - & 7.5 & - & - & 1,500 & 451,942 & 1.360 & 9155 & 0 \\
\hline
\end{tabular}

Based on these results, the best system configuration for Port Harcourt sites is hybrid PV-diesel-battery system, while PV-wind-diesel-battery is considered optimal for the rest locations (Iseyin, Sokoto, Maiduguri, Jos and Enugu). The optimal configuration obtained for Jos has the lowest NPC $(\$ 68,585)$ and COE $(0.207 \$ / \mathrm{kWh})$ of all the sites considered, followed by Sokoto site with $\$ 71,210 \mathrm{NPC}$ and $0.215 \$ / \mathrm{kWh}$ COE. The lowest NPC and COE obtained from these sites is due to high solar and wind resources availability in the sites as compared to other sites.

Since the conventional stand-alone diesel generator is presently employed in the selected rural healthcare facilities, it is thereby considered as the base case simulation. It is selected in order to allow a comparison to be made regarding the total savings that can be made in terms of cost and emission when renewable energy sources are included for the design and implementation of the hybrid power system. This configuration (Diesel-alone system) is observed to be the worst configuration with highest NPC $(\$ 451,942)$ and COE $(1.360 \$ / \mathrm{kWh})$. Although it has the least initial capital cost $(\$ 1,500)$ among other system configurations, high fuel consumption due to longer hours of operation of the generator and its associated maintenance cost has led to it high NPC. It is also noted that the COE of a diesel-alone system is more than four times optimal 
configuration in all the selected sites. This observation has demonstrated that configuration with the lowest capital cost, may not necessarily be the configuration with the lowest cost of energy.

Conversely, the third optimum configuration NPC (diesel-battery system) cost $45 \%$ more than the best optimal configuration in the entire sites. Therefore, addition of renewable energy sources (wind and solar PV) and batteries to the existing diesel-alone system in the selected sites is considered a good investment in terms of fuel savings and emission reduction.

\subsection{Energy production of each component in optimal system configuration}

Previous researches have demonstrated that RE system performance analysis for a year is sufficient for planning and decision-making $[15,68]$. This is because the historical RE data of a location is similar over the years, and different from the historical data of another location. While some components will be replaced during the 25-year project lifetime, the yearly energy yield is considered as the baseline energy generation level for any year during the system's useful operating years. Therefore, the energy production of each hybrid system components for in one-year horizon is discussed.

\subsubsection{Solar PV}

The capacity as well as number of solar panel selected in each sites depends on the amount of solar radiation received at each location and the site load profile. In order to achieve maximum power output from each module, the PV panel is expected to be inclined at optimal tilt angles and adjusted on seasonal basis. The maximum PV output power, annual PV production (kWh) and percentage PV contribution in the optimal hybrid system at each sites is presented in Table 8.

Table 8: PV output power contribution at the selected site

\begin{tabular}{|l|c|c|c|}
\hline Sites & $\begin{array}{c}\text { Maximum power } \\
\text { output (kW) }\end{array}$ & $\begin{array}{c}\text { Total annual energy } \\
\text { production (kWh) }\end{array}$ & $\begin{array}{c}\text { Percentage } \\
\text { contribution (\%) }\end{array}$ \\
\hline Iseyin & 4.866 & 7,179 & 72.5 \\
\hline Sokoto & 3.241 & 5,600 & 36.3 \\
\hline Maiduguri & 4.941 & 8,840 & 74.9 \\
\hline Jos & 3.400 & 5,672 & 34.3 \\
\hline Enugu & 4.468 & 6,665 & 54.2 \\
\hline Port Harcourt & 5.642 & 8,189 & 83.5 \\
\hline
\end{tabular}

At this juncture, it should be noted that out of all the high solar radiation potential sites, only Maiduguri has higher PV contribution (74.9\%) in the energy mix, while the other site (Sokoto and Jos) gives priority to wind turbine contribution than PV, due to high wind speed potential of the sites. On the other hand, both Iseyin and Port Harcourt favors high PV contribution despite the medium-high solar radiation potential experience at the site, but due to low wind speed experience in both sites since the developed energy management prioritize the use of RE sources over the diesel generator.

\subsubsection{Wind turbine}

The selection of types and sizes of wind turbine is based on the potential of a high wind speed regime in any particular site. Table 9 presents the maximum power output, total annual wind energy production and percentage contribution of wind energy at each site. We observe a higher percentage contribution of wind turbine at both Jos and Sokoto site due to a high wind speed regime experienced in both sites. 
Table 9: Wind turbine contribution at the selected site

\begin{tabular}{|l|c|c|c|}
\hline Sites & $\begin{array}{c}\text { Maximum Power } \\
\text { output (kW) }\end{array}$ & $\begin{array}{c}\text { Total annual energy } \\
\text { production (kWh) }\end{array}$ & $\begin{array}{c}\text { Percentage } \\
\text { contribution (\%) }\end{array}$ \\
\hline Iseyin & 1.230 & 1,474 & 14.9 \\
\hline Sokoto & 2.460 & 9,441 & 61.2 \\
\hline Maiduguri & 1.230 & 2,603 & 22.1 \\
\hline Jos & 2.460 & 10,572 & 63.9 \\
\hline Enugu & 2.460 & 5,207 & 42.3 \\
\hline Port Harcourt & - & - & - \\
\hline
\end{tabular}

\subsubsection{Diesel generator}

The maximum power output, total annual energy output, hours of operation and percentage contribution of diesel generator in the optimal hybrid system configuration in each site is presented in Table $\mathbf{1 0}$.

Table 10: Diesel generator contribution at the selected site

\begin{tabular}{|l|c|c|c|c|}
\hline Sites & $\begin{array}{c}\text { Maximum Power } \\
\text { output (kW) }\end{array}$ & $\begin{array}{c}\text { Total annual energy } \\
\text { production (kWh) }\end{array}$ & $\begin{array}{c}\text { Operating } \\
\text { hours (hr/yr.) }\end{array}$ & $\begin{array}{c}\text { Percentage } \\
\text { contribution (\%) }\end{array}$ \\
\hline Iseyin & 5.0 & 1,245 & 288 & 12.6 \\
\hline Sokoto & 5.0 & 376 & 144 & 2.44 \\
\hline Maiduguri & 5.0 & 353 & 113 & 2.99 \\
\hline Jos & 5.0 & 297 & 119 & 1.79 \\
\hline Enugu & 5.0 & 432 & 126 & 3.51 \\
\hline Port Harcourt & 5.0 & 1,617 & 380 & 16.5 \\
\hline
\end{tabular}

\subsubsection{Battery energy storage capacity}

The hourly battery SOC over a period of one year in the selected locations is presented in Figure 10. From this figure, it is observed that the battery SOC at both Sokoto and Jos sites is constantly at full capacity over the year except for few hours. This is due to the enormous potential of RE resources at both sites, resulting in the availability of RE sources to meet the clinic load demand at all time. Iseyin and Port Harcourt sites, on the other hand, experienced higher battery depletion compare to other sites especially during the Month of July, August and September (rainy season). This experience is due to low potential of RE sources in meeting the clinic load demand, thus resulting in depletion of the battery to its minimum state of charge ( $\mathrm{SOC}_{\min }$ ) before the generator comes up to supply the load and charges the batteries. As earlier discussed, the number of hours of operation of a diesel generator at these sites is more than the other sites due to the above reason. 

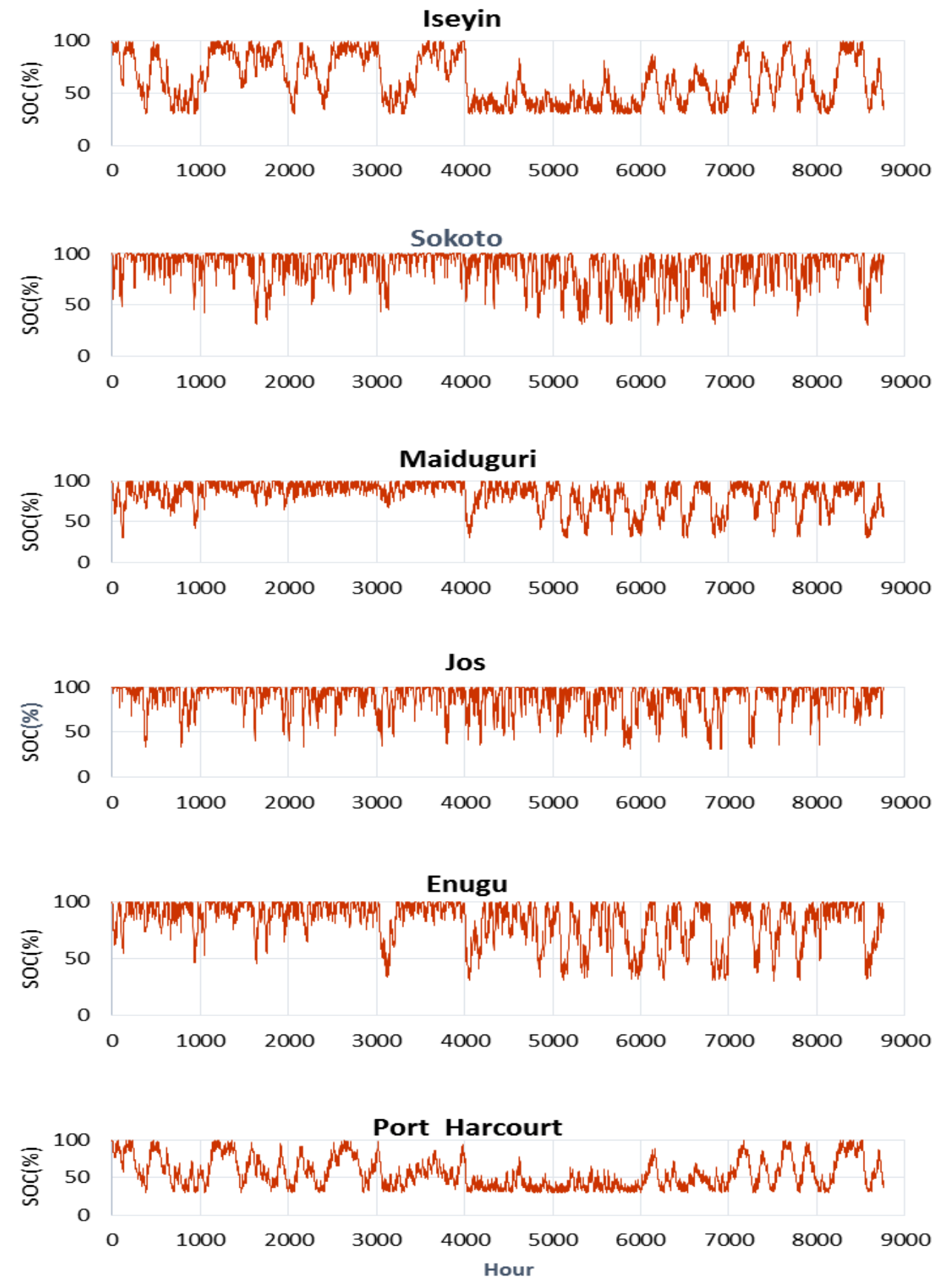

Figure 10: Hourly battery SOC over a year at the selected sites

\subsubsection{Combined energy production}

Contribution of each energy source (wind turbine, solar PV and diesel generator) in meeting the load demand and the state of charge of batteries for the optimal hybrid system configuration case in Iseyin rural 
healthcare facility for two specific month of in a year ; January (dry season) and August (rainy season) is shown in Figures 11 and 12 respectively.
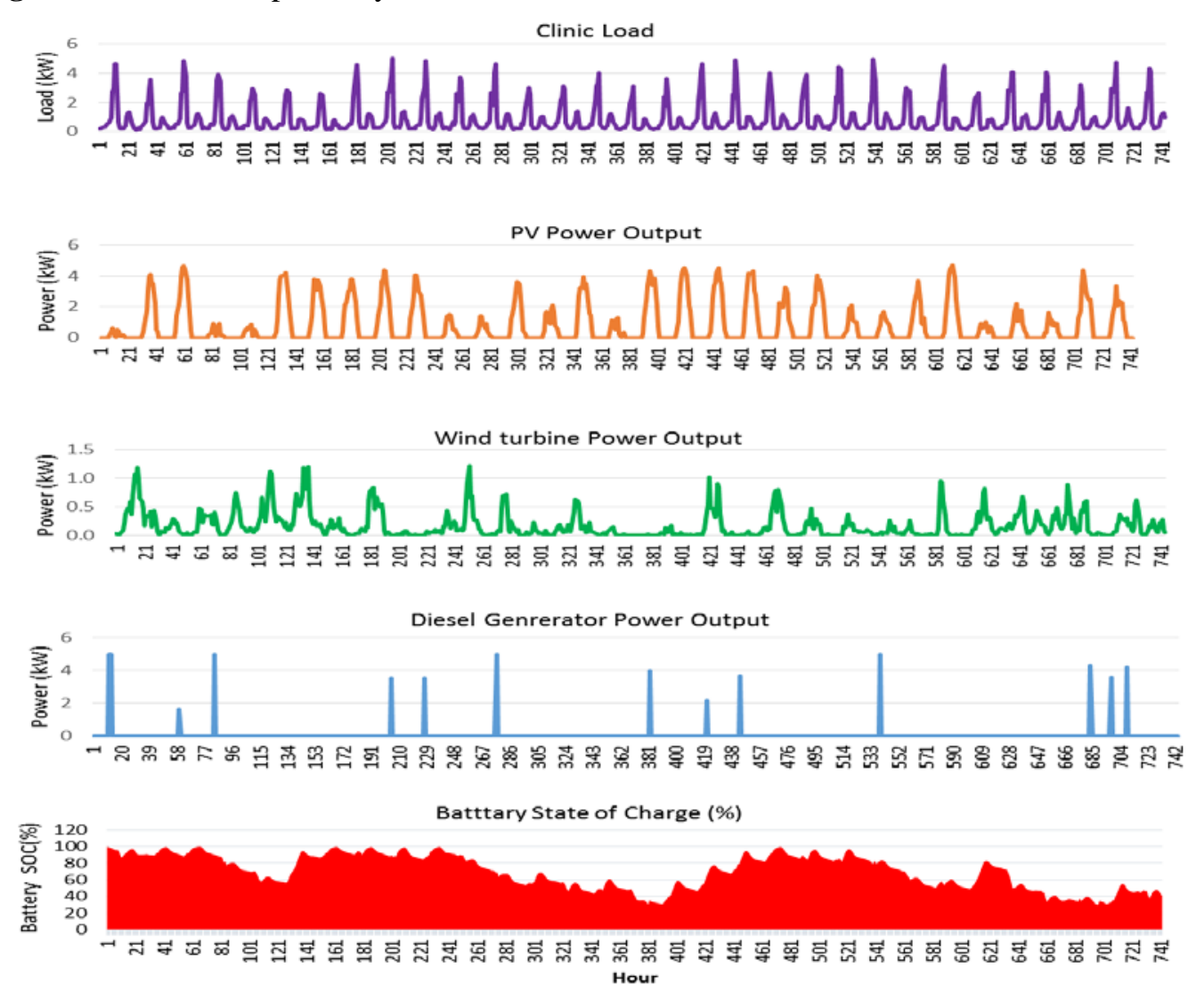

Figure 11: Energy production of various energy sources and battery SOC of typical January month in Iseyin

These plots show the typical operation hour of the diesel generator in each of the specified months. A typical month of January in Nigeria is considered as dry season month due to clear sky conditions usually experienced during this month and more sunshine hours, leading to a good amount of solar radiation that encouraged PV power production. While August month in the entire region in Nigeria is considered as a rainy season month due to a large amount of rainfall during this period, hence cloudy sky leading low solar radiation potential that adversely affects PV power production.

As can be observed from Figure 11, the battery state of charge remained full due to good amount of solar radiation incident on the PV panel during this month, leading to high power output from the PV panel to meet the load demand. Wind turbine also contributed in meeting the load demand as can been seen in the Figure. During this period, the number of hour of operation of diesel generator is limited due to sufficient amount of energy from RE sources to power the load and charges the battery.

However, in the second scenario (August month), we observed constant depletion in battery storage capacity due to insufficient power production from both PV and wind energy sources as a result of changes in the weather condition. During this period, high number of start/stop of diesel generator operation is expected to meet the deficit of RE sources in meeting the clinic load demand as well as for charging the battery. It should, however, be noted that the battery capacity should not be depleted beyond the specified (30\%) limit as already been designed with the energy management approach. This is done in order to avoid shortening the lifespan of the batteries. 

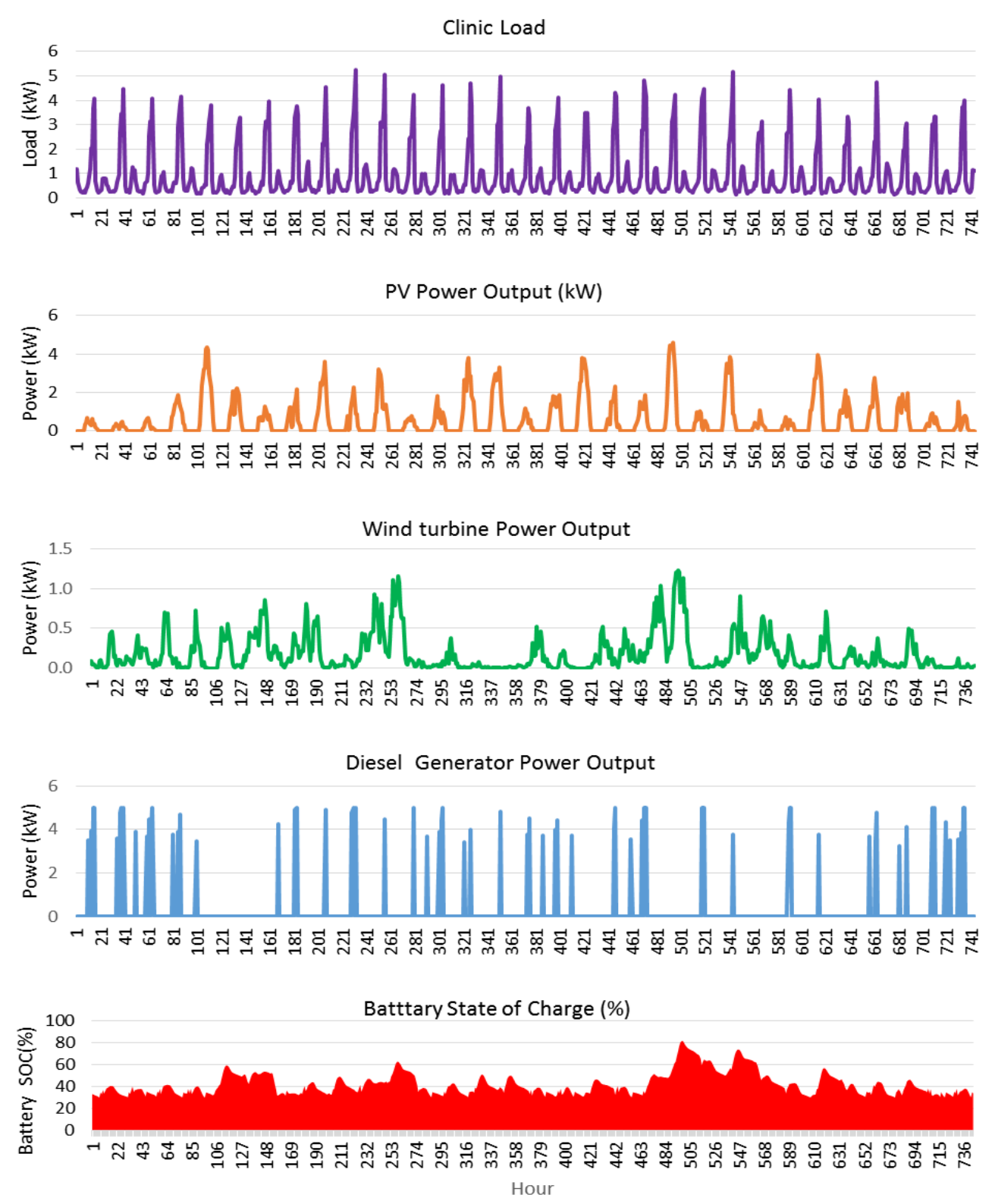

Figure 12: Energy production of various energy sources and battery SOC of a typical August month in Iseyin

\subsection{Pollutant emission analysis}

Figure 13 shows the annual carbon dioxide $\left(\mathrm{CO}_{2}\right)$ pollutant emission for the best optimal configurations in each of the selected sites, while Figure 14 shows the same analysis in comparison with diesel-only system configuration. The optimal hybrid renewable system configurations emitted 1,119.8, 374.4, 337.13, 298.66, 404.83 and 1,459.2 kg/year of $\mathrm{CO}_{2}$ at Iseyin, Sokoto, Maiduguri, Jos, Enugu and Port-Harcourt respectively, 
while the diesel-only system emits $24,107 \mathrm{~kg} / \mathrm{yr}$. Therefore, the hybrid systems present savings of $85.8 \%$ in total $\mathrm{CO}_{2}$ emissions compared with diesel equivalents.

\section{Pollutant Emission $\left(\mathrm{CO}_{2}\right)$}

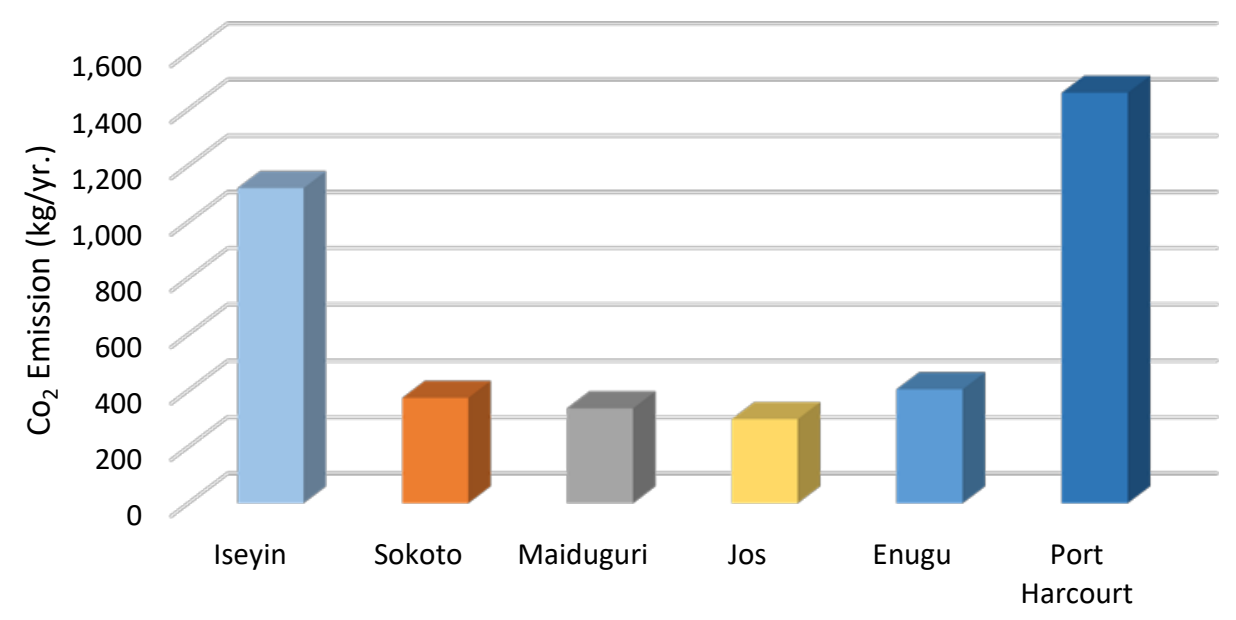

Sites

Figure 13: Comparison of $\mathrm{CO}_{2}$ pollutant emission in the entire site

Since diesel generator consumed diesel fuel to produce power, thus the higher diesel operating hours experienced at both Port Harcourt and Iseyin site has led to higher $\mathrm{CO}_{2}$ emission as seen in Figure 13. On the other hand, the remaining sites experienced low emission due to high availability of renewable energy resources leading to utilizationof hybrid PV/wind to power the rural health clinics majority of the time during the year rather than diesel generator system.

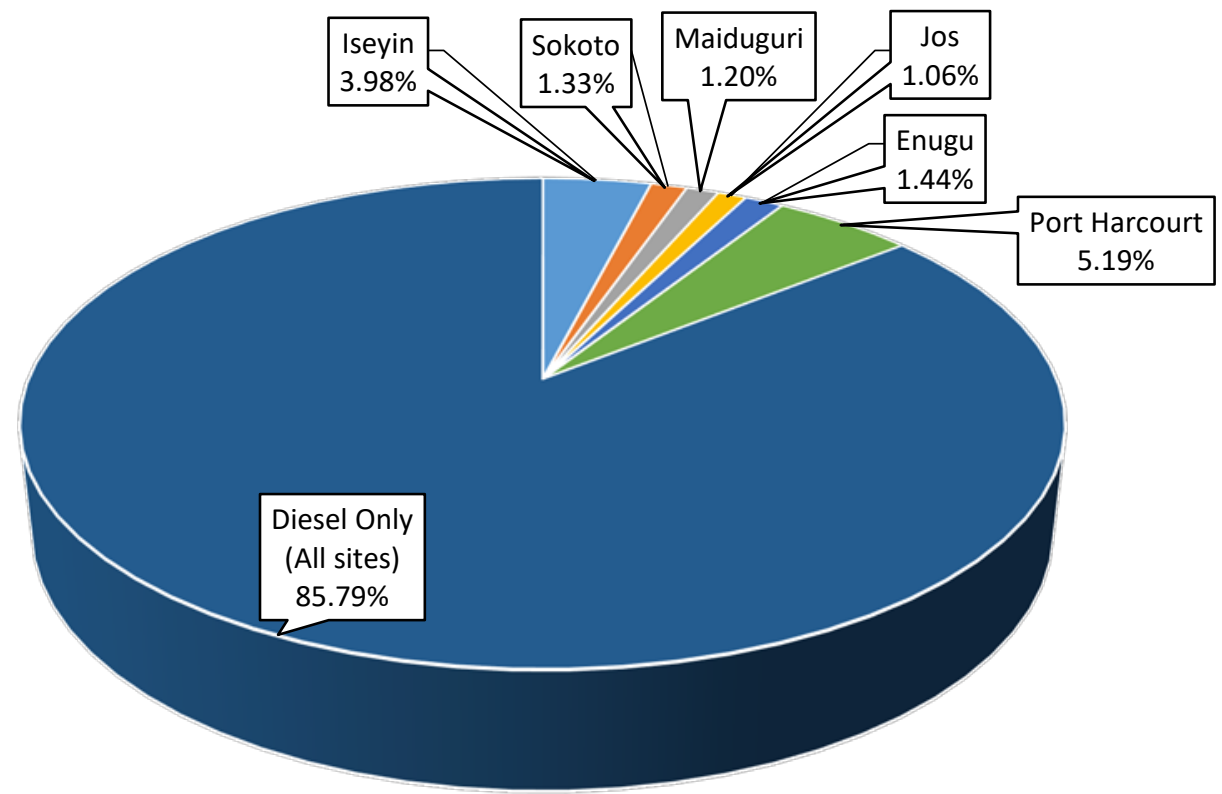

Figure 14: Comparison of $\mathrm{CO}_{2}$ emission in optimal system configuration and diesel-only system in the selected sites 
As a result, a total of 95.4, 98.4, 98.6, 98.8, 98.3 and 93.9\% of $\mathrm{CO}_{2}$ emission would be curtailed if a hybrid renewable energy system configuration is adopted at Iseyin, Sokoto, Maiduguri, Jos, Enugu and Port-Harcourt respectively. Based on the observation from Figure 14 and bearing in mind the effect of pollution into the environment, it can be concluded that the best suitable sites for HRES configuration comprising PV, wind, diesel and battery are Jos, Maiduguri, Sokoto and Enugu rural healthcare facilities. This is basically due to the highest percentage of $\mathrm{CO}_{2}$ emission reduction in the locations as well as low NPC compared to other locations as earlier stated.

\section{Conclusions}

This study identified a lack of modern electricity supply as a major impediment to proper functioning of the healthcare centers in the rural areas, contributing to high maternal and child mortality rates in a country. It is against this backdrop that the research work has focused on how to address the problem so that the healthcare centers or clinics in the remote areas can provide timely delivery of medical services for the concerned people. This research study has presented the simulation and analysis of stand-alone hybrid renewable energy systems for basic healthcare services in the rural areas, where there is no grid energy supply or the supply from the existing grid is erratic and unreliable. It has considered the energy configurations fueled by the available solar, wind and diesel energy resources of six different locations in Nigeria under different environmental conditions such as the solar irradiation, wind and ambient temperature. The locations used as test cases are North-east (Maiduguri), North-west (Sokoto), North-central (Jos), South-east (Enugu), South-west (Iseyin) and South-south (Port-harcourt).

The study has employed standard off-grid energy systems methodologies supported by the HOMER tool, IEC standards and relevant studies in the literature for the simulation and analysis of the proposed hybrid electricity systems for the intended healthcare centers across Nigeria. In addition, a reallife load demand profile of a standard rural healthcare center in the country has been used as the basis of the analysis of the energy system. This provides a practical approach to understanding and ascertaining the users' energy requirements, rather than making assumptions. Therefore, the total demand of about 24 $\mathrm{kWh} / \mathrm{d}$ used in this paper has been developed by considering all the different appliances in the health center and their daily hours of operation.

The technical analysis involved determining the approapriate sizes of different components of the hybrid systems, their annual energy generatio and the battery state of charge. These have been done by using the HOMER to optimise the different energy models or configurations that can meet the daily energy demand of the healthcare centers. However,the economic analysis examined the initial capital cost, net present cost and the cost of energy, while the environmental analysis has been considered in terms of the quantity of carbon emissions that may be avoided supposing the proposed hybrid electricity systems are implemented in the specified locations. It is expected the results of the analysis of the technical, economic and environmental aspects of the design may be useful for planning stand-alone energy generation systems for remote healthcare centers in Nigeria.

The major findings of the research study are summarised as follows:

- The research reveals that the wind system at Iseyin and Maiduguri have the lowest wind power output of $1.23 \mathrm{~kW}$, while those systems at Sokoto, Jos and Enugu have the highest power output of the same value of $2.46 \mathrm{~kW}$. This is because Iseyin location has a low wind power density of 85.33 W/m $\mathrm{m}^{2}$ compared to 516.57, 741.22 and $172.38 \mathrm{~W} / \mathrm{m}^{2}$ for the other three locations, including Maiduguri. Similarly, the wind power system at Iseyin and Maiduguri produced annual energy of 1,474 and 2,603 kWh, respectively, compared to 9, 441, 10,572 and ,207 kWh for Sokoto, Jos 
and Enugu. The results further show that even though Iseyin and Maiduguri have the same maximum wind power output, they have different energy output. This is also the case with Sokoto, Jos and Enugu with the same wind power capacity of $2.46 \mathrm{~kW}$ but different annual energy output. Sokoto and Jos may be considered as a potential site for relatively high wind energy generation compared to the remaining locations that have low wind speed regimes. This analysis demonstrates that an environmental factor of a location such as the wind speed determines the possible energy output of a wind power system.

- Furthermore, the study reveals that though all the locations experience good sunshine, there is still disparity in the annual energy generation across the country determined by the solar irradiation and temperature factors of the locations. The system at Maiduguri that has a power output of $4.941 \mathrm{~kW}$ and produced the highest annual energy output of 8,840 $\mathrm{kWh}$, while the system at Jos has power of $3.4 \mathrm{~kW}$ and the lowest annual energy output of 5,672 kWh. It is clear from the results that the system at Jos with the lowest solar energy output has the highest wind energy output, while the system at Maiduguri with relatively lower wind energy output produced the highest annual solar energy output. Therefore, the percentage contribution of each of the renewable energy sources differs by its potential in the specified locations. The academic conclusions on this is that the complementary characteristics of the constituent renewable energy technologies justifies the hybrid energy configuration as a better option compared to a single source system based on solar or wind alone.

- In addition, the diesel generator enhances the reliability of the hybrid system to forestall exceeding the battery's minimum state of charge and a loss of power supply to the health centers over the 24-hour period. The battery state of charge results demonstrate that it is possible to achieve off-grid energy systems that can be operated within the acceptable battery state of charge limits with a minimum of 0.3 in this study.

- The economic analysis shows that the system at Jos has the lowest net present cost and cost of energy due to the location's high wind and moderate solar energy resources availability compared to the other locations. The system also has the lowest PV capacity of $4 \mathrm{~kW}$ and a wind capacity of $2 \mathrm{~kW}$. The system at Port-Harcourt has the highest net present cost and the cost of energy in the $\mathrm{PV} /$ wind/diesel/battery configuration because of its relatively higher PV capacity and possibly lower renewable energy generation. Therefore, the practical implication of a system having the highest annual renewable energy generation such as the one at Jos is that has the minimum diesel energy generation requirement. However, the system at Port-Harcourt has the highest generator requirements. The study also observed that a 100\% diesel system has the highest cost of energy. This study finds that the higher the annual energy generated by a system, the lower the cost of the produced energy per kWh.

- The research demonstrated that $\mathrm{CO}_{2}$ of $24,107 \mathrm{~kg} / \mathrm{yr}$ is likely to emit by providing electricity to the health centers through a diesel power generator alone. This is significantely higher than the predicted emissions, ranging from 404.83 to 1,459.2 kg/yr, obtained by using the PV/wind/diesel/battery hybrid power systems in the locations. The lowest and the highest values of emissions are obtained for Jos and Port-Harcourt, which is consistent with the observation earlier presented. Therefore, the proposed hybrid solutions promise lower environmental impacts in terms of carbon emissions when they are implemented due to the high percentage contribution of the renewable energy resources and low diesel energy consumption. 
The implementation of the proposed hybrid renewable energy model in the rural health clinics will ensure reliability of power supply due to the complementary characteristics of the constituent renewable energy technologies in the hybrid system; elongation of the operating hours in rural health clinics due to availability of general lighting; attraction of more medical personnel (doctors and nurses), leading to availability of wider range of medical services, since experts tends to be attracted to rural areas having access to electricity; communicable disease prevention due to constant sensitization and awareness via TV/VCR jingles in the clinics; improved cold-chain vaccines, drugs, blood and other medical perishable preservation due to availability of electricity to power refrigerators; better emergency services and improved referral system via RF communication to the secondary healthcare centres among others for better healthcare delivery.

Though, Nigeria has been used a test case in this study, the analysis and the contributions of the paper may be useful for understanding and planning small-scale hybrid electricity generation in other parts of the world. Therefore, the research form a basis for a better understanding of and addressing the problem of a lack of electricity supply to healthcare centers within villages and peri-urban areas around the world.

\section{Acknowledgments}

The first author, a Commonwealth Rutherford Fellow funded by the UK government would like to thank Commonwealth Scholarship Commission in the UK, Bright Spark Scholarship of University of Malaya, Malaysia and Centre for Renewable Energy Systems Technology, Loughborough University, UK for providing the enabling environment for this research. In addition, the entire authors appreciate the Nigerian Meteorological Agency (NIMET) for providing the required meteorological data for this research.

\section{REFERENCES}

[1] IRENA. (2012). International Off-Grid Renewable Energy Conference :Key findings and recommendations. Available: http://www.irena.org

[2] Practical Action, "Poor people’s energy outlook ", ed. Rugby, UK., 2013.

[3] H. Adair-Rohani, K. Zukor, S. Bonjour, S. Wilburn, A. C. Kuesel, R. Hebert, et al., "Limited electricity access in health facilities of sub-Saharan Africa: a systematic review of data on electricity access, sources, and reliability," Global Health: Science and Practice, vol. 1, pp. 249-261, 2013.

[4] R. K. Akikur, R. Saidur, H. W. Ping, and K. R. Ullah, "Comparative study of stand-alone and hybrid solar energy systems suitable for off-grid rural electrification: A review," Renewable and Sustainable Energy Reviews, vol. 27, pp. 738-752, 11// 2013.

[5] L. Olatomiwa, S. Mekhilef, A. Huda, and K. Sanusi, "Techno-economic analysis of hybrid PV-dieselbattery and PV-wind-diesel-battery power systems for mobile BTS: the way forward for rural development," Energy Science \& Engineering, 2015.

[6] D. O. Akinyele and R. K. Rayudu, "Community-based hybrid electricity supply system: A practical and comparative approach," Applied Energy, vol. 171, pp. 608-628, 2016/06/01/ 2016.

[7] D. O. Akinyele, N. K. C. Nair, R. K. Rayudu, and B. Chakrabarti, "Decentralized energy generation for end-use applications: Economic, social and environmental benefits assessment," in 2014 IEEE Innovative Smart Grid Technologies - Asia (ISGT ASIA), 2014, pp. 84-89.

[8] O. Roche and R. E. Blanchard, "Design of a solar energy centre for providing lighting and incomegenerating activities for off-grid rural communities in Kenya," Renewable Energy, vol. 118, pp. 685-694, 2018.

[9] D. O. Akinyele, "Environmental performance evaluation of a grid-independent solar photovoltaic power generation (SPPG) plant," Energy, vol. 130, pp. 515-529, 2017/07/01/ 2017. 
[10] S. Bhakta, V. Mukherjee, and B. Shaw, "Techno-economic analysis and performance assessment of standalone photovoltaic/wind/hybrid power system in Lakshadweep islands of India," Journal of Renewable and Sustainable Energy, vol. 7, p. 063117, 2015.

[11] D. Akinyele, R. Rayudu, and R. E. Blanchard, "Sustainable microgrids for energy-poor communities: a spotlight on the planning dimensions," 2016.

[12] L. M. Halabi, S. Mekhilef, and M. Hossain, "Performance evaluation of hybrid adaptive neuro-fuzzy inference system models for predicting monthly global solar radiation," Applied Energy, vol. 213, pp. 247261, 2018.

[13] Y. Azoumah, D. Yamegueu, P. Ginies, Y. Coulibaly, and P. Girard, "Sustainable electricity generation for rural and peri-urban populations of sub-Saharan Africa: the "flexy-energy" concept," Energy Policy, vol. 39, pp. 131-141, 2011.

[14] L. Olatomiwa, "Optimal configuration assessments of hybrid renewable power supply for rural healthcare facilities," Energy Reports, vol. 2, pp. 141-146, 2016.

[15] D. Akinyele and R. Rayudu, "Strategy for developing energy systems for remote communities: Insights to best practices and sustainability," Sustainable Energy Technologies and Assessments, vol. 16, pp. 106-127, 2016.

[16] S. C. Bhattacharyya, "Review of alternative methodologies for analysing off-grid electricity supply," Renewable and Sustainable Energy Reviews, vol. 16, pp. 677-694, 1// 2012.

[17] A.-K. Daud and M. S. Ismail, "Design of isolated hybrid systems minimizing costs and pollutant emissions," Renewable energy, vol. 44, pp. 215-224, 2012.

[18] L. M. Halabi, S. Mekhilef, L. Olatomiwa, and J. Hazelton, "Performance analysis of hybrid PV/diesel/battery system using HOMER: A case study Sabah, Malaysia," Energy Conversion and Management, vol. 144, pp. 322-339, 2017.

[19] M. Hossain, S. Mekhilef, and L. Olatomiwa, "Performance evaluation of a stand-alone PV-wind-dieselbattery hybrid system feasible for a large resort center in South China Sea, Malaysia," Sustainable Cities and Society, vol. 28, pp. 358-366, 2017.

[20] M. L. Kolhe, K. I. U. Ranaweera, and A. S. Gunawardana, "Techno-economic sizing of off-grid hybrid renewable energy system for rural electrification in Sri Lanka," Sustainable Energy Technologies and Assessments, vol. 11, pp. 53-64, 2015.

[21] A. Ghafoor and A. Munir, "Design and economics analysis of an off-grid PV system for household electrification," Renewable and Sustainable Energy Reviews, vol. 42, pp. 496-502, 2015.

[22] A. H. Mamaghani, S. A. A. Escandon, B. Najafi, A. Shirazi, and F. Rinaldi, "Techno-economic feasibility of photovoltaic, wind, diesel and hybrid electrification systems for off-grid rural electrification in Colombia," Renewable Energy, vol. 97, pp. 293-305, 2016.

[23] A. Ghasemi, A. Asrari, M. Zarif, and S. Abdelwahed, "Techno-economic analysis of stand-alone hybrid photovoltaic-diesel-battery systems for rural electrification in eastern part of Iran-A step toward sustainable rural development," Renewable and Sustainable Energy Reviews, vol. 28, pp. 456-462, 12// 2013.

[24] M. Belouda, A. Jaafar, B. Sareni, X. Roboam, and J. Belhadj, "Integrated optimal design and sensitivity analysis of a stand alone wind turbine system with storage for rural electrification," Renewable and Sustainable Energy Reviews, vol. 28, pp. 616-624, 2013.

[25] M. K. Shahzad, A. Zahid, T. ur Rashid, M. A. Rehan, M. Ali, and M. Ahmad, "Techno-economic feasibility analysis of a solar-biomass off grid system for the electrification of remote rural areas in Pakistan using HOMER software," Renewable energy, vol. 106, pp. 264-273, 2017.

[26] P. Kumar and S. Deokar, "Optimal design configuration using HOMER," in Advances in Systems, Control and Automation, ed: Springer, 2018, pp. 101-108.

[27] A. Franco, M. Shaker, D. Kalubi, and S. Hostettler, "A review of sustainable energy access and technologies for healthcare facilities in the Global South," Sustainable Energy Technologies and Assessments, vol. 22, pp. 92-105, 2017.

[28] S. Mandelli, J. Barbieri, R. Mereu, and E. Colombo, "Off-grid systems for rural electrification in developing countries: Definitions, classification and a comprehensive literature review," Renewable and Sustainable Energy Reviews, vol. 58, pp. 1621-1646, 2016. 
[29] R. Siddaiah and R. Saini, "A review on planning, configurations, modeling and optimization techniques of hybrid renewable energy systems for off grid applications," Renewable and Sustainable Energy Reviews, vol. 58, pp. 376-396, 2016.

[30] IEEE, " Guide for array and battery sizing in stand-alone photovoltaic (PV) systems, IEEE Std. 1562," ed: IEEE, 2007, pp. 1-34.

[31] IEEE, "IEEE Guide for Optimizing the Performance and Life of Lead-Acid Batteries in Remote Hybrid Power Systems. IEEE Std. 1561," ed, 2007, pp. 1-35.

[32] IEC, "Recommendations for small renewable energy and hybrid systems for rural electrification, IEC Std. 62257," ed: IEC, 2007, pp. 1-27.

[33] L. Bartolucci, S. Cordiner, V. Mulone, V. Rocco, and J. L. Rossi, "Hybrid renewable energy systems for renewable integration in microgrids: Influence of sizing on performance," Energy, vol. 152, pp. 744-758, 2018.

[34] K. Anoune, M. Bouya, A. Astito, and A. B. Abdellah, "Sizing methods and optimization techniques for PV-wind based hybrid renewable energy system: A review," Renewable and Sustainable Energy Reviews, vol. 93, pp. 652-673, 2018.

[35] Y. Sawle, S. Gupta, and A. K. Bohre, "Review of hybrid renewable energy systems with comparative analysis of off-grid hybrid system," Renewable and Sustainable Energy Reviews, 2017.

[36] P. Ganguly, A. Kalam, and A. Zayegh, "Solar-wind hybrid renewable energy system: current status of research on configurations, control, and sizing methodologies," in Hybrid-Renewable Energy Systems in Microgrids, ed: Elsevier, 2018, pp. 219-248.

[37] S. S. Dihrab and K. Sopian, "Electricity generation of hybrid PV/wind systems in Iraq," Renewable Energy, vol. 35, pp. 1303-1307, 2010.

[38] A. Hiendro, R. Kurnianto, M. Rajagukguk, and Y. M. Simanjuntak, "Techno-economic analysis of photovoltaic/wind hybrid system for onshore/remote area in Indonesia," Energy, vol. 59, pp. 652-657, 2013.

[39] O. S. Ohunakin, M. S. Adaramola, O. M. Oyewola, and R. O. Fagbenle, "Solar energy applications and development in Nigeria: drivers and barriers," Renewable and Sustainable Energy Reviews, vol. 32, pp. 294-301, 2014.

[40] M. S. Adaramola, "Estimating global solar radiation using common meteorological data in Akure, Nigeria," Renewable Energy, vol. 47, pp. 38-44, 2012.

[41] M. Okundamiya and A. Nzeako, "Empirical model for estimating global solar radiation on horizontal surfaces for selected cities in the six geopolitical zones in Nigeria," Journal of Control Science and Engineering, vol. 2011, p. 9, 2011.

[42] L. Olatomiwa, S. Mekhilef, S. Shamshirband, and D. Petkovic, "Potential of support vector regression for solar radiation prediction in Nigeria," Natural Hazards, vol. 77, pp. 1055-1068, 2015.

[43] L. Olatomiwa, S. Mekhilef, and S. Shamshirband, "Global Solar Radiation Forecasting Based on SVMWavelet Transform Algorithm," International Journal of Intelligent Systems and Applications(IJISA), vol. 8, pp. 19-26, 2016.

[44] L. Olatomiwa, S. Mekhilef, S. Shamshirband, and D. Petković, "Adaptive neuro-fuzzy approach for solar radiation prediction in Nigeria," Renewable and Sustainable Energy Reviews, vol. 51, pp. 1784-1791, 2015.

[45] L. Olatomiwa, S. Mekhilef, S. Shamshirband, K. Mohammadi, D. Petković, and C. Sudheer, "A support vector machine-firefly algorithm-based model for global solar radiation prediction," Solar Energy, vol. 115, pp. 632-644, 2015.

[46] M. S. Adaramola, O. M. Oyewola, O. S. Ohunakin, and O. O. Akinnawonu, "Performance evaluation of wind turbines for energy generation in Niger Delta, Nigeria," Sustainable Energy Technologies and Assessments, vol. 6, pp. 75-85, 2014.

[47] O. S. Ohunakin, "Wind resource evaluation in six selected high altitude locations in Nigeria," Renewable Energy, vol. 36, pp. 3273-3281, 2011.

[48] NIMET. (2014). Nigerian Meteorological Agency Available: htttp://www.nimet.gov.ng

[49] L. Olatomiwa, S. Mekhilef, and O. S. Ohunakin, "Hybrid renewable power supply for rural health clinics (RHC) in six geo-political zones of Nigeria," Sustainable Energy Technologies and Assessments, vol. 13, pp. 1-12, 2016.

[50] USAID. (2014). Powering Health. Available: http://www.poweringhealth.org/index.php 
[51] M. Ismail, M. Moghavvemi, and T. Mahlia, "Techno-economic analysis of an optimized photovoltaic and diesel generator hybrid power system for remote houses in a tropical climate," Energy Conversion and Management, vol. 69, pp. 163-173, 2013.

[52] T. Lambert, P. Gilman, and P. Lilienthal, "Micropower system modeling with HOMER," Integration of alternative sources of energy, vol. 1, pp. 379-385, 2006.

[53] S. O. Ohunakin, S. J. Ojolo, S. B. Ogunsina, and R. R. Dinrifo, "Analysis of cost estimation and wind energy evaluation using wind energy conversion systems (WECS) for electricity generation in six selected high altitude locations in Nigeria," Energy Policy, vol. 48, pp. 594-600, 2012.

[54] O. S. Ohunakin and O. O. Akinnawonu, "Assessment of wind energy potential and the economics of wind power generation in Jos, Plateau State, Nigeria," Energy for Sustainable Development, vol. 16, pp. 78-83, 2012.

[55] S. Mathew, Wind energy: fundamentals, resource analysis and economics vol. 1: Springer, 2006.

[56] D. Wood, "Small wind turbines for remote power and distributed generation," Wind Engineering, vol. 34, pp. 241-254, 2010.

[57] R. Dufo-López and J. L. Bernal-Agustín, "Multi-objective design of PV-wind-diesel-hydrogen-battery systems," Renewable energy, vol. 33, pp. 2559-2572, 2008.

[58] M. Torres and L. A. Lopes, "Inverter-based diesel generator emulator for the study of frequency variations in a laboratory-scale autonomous power system," Energy and Power Engineering, vol. 5, p. 274, 2013.

[59] IEC, "Recommendations for small renewable energy and hybrid systems for rural electrification (Part 7: Generators). ," ed: IEC, 2008, pp. 1-19.

[60] NREL, "HOMER PRO Index," ed, 2015.

[61] S. Diaf, D. Diaf, M. Belhamel, M. Haddadi, and A. Louche, "A methodology for optimal sizing of autonomous hybrid PV/wind system," Energy Policy, vol. 35, pp. 5708-5718, 11// 2007.

[62] M. S. Adaramola, S. S. Paul, and O. M. Oyewola, "Assessment of decentralized hybrid PV solar-diesel power system for applications in Northern part of Nigeria," Energy for Sustainable Development, vol. 19, pp. 72-82, 2014.

[63] D. Akinyele, R. Rayudu, and N. Nair, "Grid-independent renewable energy solutions for residential use: The case of an off-grid house in wellington, New Zealand," in Power and Energy Engineering Conference (APPEEC), 2015 IEEE PES Asia-Pacific, 2015, pp. 1-5.

[64] Ngpricehunter. (May 12, 2015). Available: http://www.ngpricehunter.com/

[65] mygadgetsmall. (May 20, 2015). Available: http://www.mygadgetsmall.com/

[66] Worldbank. (2018). Available: http://data.worldbank.org

[67] D. Elliott and M. Schwartz, "Wind energy potential in the United States," Pacific Northwest Laboratory PNL-SA-23109, Richland, WA, 1993.

[68] A. Kumar, P. Mohanty, D. Palit, and A. Chaurey, "Approach for standardization of off-grid electrification projects," Renewable and Sustainable Energy Reviews, vol. 13, pp. 1946-1956, 2009. 